\title{
Livelihood Assessment and Occupational Health Hazard of the Ship-Breaking Industry Workers at Chattogram, Bangladesh
}

\author{
Abu Faisal Ahamad ${ }^{1,+}{ }^{\text {, Petra Schneider }}{ }^{2}$ D, Romaza Khanum ${ }^{3}$, Mohammad Mojibul Hoque Mozumder ${ }^{4}$, \\ Sabrina Jannat Mitu ${ }^{1}$ and Md. Mostafa Shamsuzzaman ${ }^{1, *,+}$ id \\ 1 Department of Coastal and Marine Fisheries, Sylhet Agricultural University, Sylhet 3100, Bangladesh; \\ abufaisalahamad@gmail.com (A.F.A.); mitusabrina42@gmail.com (S.J.M.) \\ 2 Department for Water, Environment, Civil Engineering and Safety, University of Applied Sciences \\ Magdeburg-Stendal, Breitscheidstraße 2, D-39114 Magdeburg, Germany; Petra.Schneider@h2.de \\ 3 Department of Agricultural Economics and Policy, Sylhet Agricultural University, Sylhet 3100, Bangladesh; \\ payelsgvc@yahoo.com \\ 4 Fisheries and Environmental Management Group, Helsinki Institute of Sustainability Science (HELSUS), \\ Faculty of Biological and Environmental Sciences, University of Helsinki, 00014 Helsinki, Finland; \\ mohammad.mozumder@helsinki.fi \\ * Correspondence: shamsuzzamanmm.cmf@sau.ac.bd \\ + These authors contributed equally to this work.
}

\section{check for} updates

Citation: Ahamad, A.F.; Schneider P.; Khanum, R.; Mozumder, M.M.H.; Mitu, S.J.; Shamsuzzaman, M.M. Livelihood Assessment and Occupational Health Hazard of the Ship-Breaking Industry Workers at Chattogram, Bangladesh. J. Mar. Sci. Eng. 2021, 9, 718. https://doi.org/ 10.3390/jmse9070718

Academic Editors: Md Jahir Rizvi and Claudio Ferrari

Received: 28 May 2021

Accepted: 26 June 2021

Published: 29 June 2021

Publisher's Note: MDPI stays neutra with regard to jurisdictional claims in published maps and institutional affiliations.

Copyright: (c) 2021 by the authors. Licensee MDPI, Basel, Switzerland. This article is an open access article distributed under the terms and conditions of the Creative Commons Attribution (CC BY) license (https:/ / creativecommons.org/licenses/by/ $4.0 /)$.
Abstract: The ship-breaking industry has become a promising sector in Bangladesh by contributing to the country's primary steel demand as raw material for re-rolling mills, providing livelihood opportunities for the poor. This paper investigates the livelihood index and health hazards of workers engaged in ship-breaking activities at the Bhatiari coast of Chattogram, Bangladesh. Both qualitative and quantitative data were collected through participatory rural assessment (PRA) tools that included 128 individual interviews (II), ten focus group discussions (FGDs), and 15 key informant interviews (KIIs). The workers' livelihoods revealed that workers lack basic facilities and are exposed to occupational health hazards due to working in a risky environment. Workers of different origins claimed to have 1 to 6 years of work experience and worked 11 to $12 \mathrm{~h}$ a day. More than $60 \%$ of workers reported being injured or suffering from various physical problems such as blurred vision, abdominal pain, and skin problems. Labor-intensive and unstable occupations, limited access to medical services, poor housing and sanitation, and lack of basic safety requirements increase workers' plight. Therefore, the study offers advanced protective equipment, better medical facilities, and a safe workplace to improve the workers' livelihoods.

Keywords: livelihood index; ship breaking; occupational health hazards in coastal areas

\section{Introduction}

Ship-breaking or ship recycling is cutting and breaking apart old ships to recycle scrap metals or other materials. It is a typical activity along the coast of Bangladesh [1,2]. The shipbreaking industry of Bangladesh has captured the global market by dismantling around $47.2 \%$ of the world's vessels and currently supplying $60 \%$ of the raw materials for the local steel industry [3]. The industry has gained importance in the macro and micro-economy of poverty-stricken Bangladesh [2] and secured the second position for dismantling ships $[4,5]$. The industry has become a promising sector in Bangladesh due to low labor costs, high rates of steel utilization from recycled vessels (80-90\%), income generation, and employment opportunities for the poor. However, it is also known for low compliance with occupational health and safety standards [6,7]. With the increasing demand for raw materials for re-rolling mills and other purposes and their negative impact on the coastal environment, ships' demolition work presents a comprehensive set of challenges and opportunities for integrated coastal zone management. Energy consumption is one of the most fundamental drivers of climate change in the world. The housing sector 
averages about $35 \%$ of total energy consumption in developing countries, compared to about $20 \%$ in developed countries. In Bangladesh, per capita, energy consumption averages $344 \mathrm{kgoe}$ (kilowatts of oil equivalent), per capita power generation is $510 \mathrm{kWh}$, and access to electricity is $95 \%$, lower than its neighbors in South Asia). In China, residential energy consumption consists of roughly $10 \%$ to $11 \%$ of the country's total [7].

Ship-breaking activities are carried out in Bangladesh's coastal areas that pose a severe threat to the natural coastal environments and workers' working environments. Despite generating its profitability and income, the ship-breaking industry has been criticized for its poor working practices and low environmental standards, thus damaging the sector's image at national and international levels [7]. As a potential sector of Bangladesh, the industry is governed by many national and international laws. International regulations such as the Hong Kong International Convention 2009, the Basel Convention 1989, the MARPOL (Marine Pollution) Convention 1973/78, and International Maritime Organization (IMO) Convention 2003, the International Labor Organization (ILO) Guidelines for Safety and Health in Ship Breaking, 2004 and other international documents play an essential role in managing the environmental and safety issues associated with the shipbreaking industry in Bangladesh. Regarding ship dismantling, the Hong Kong International Convention for the Safe and Environmentally Sound Recycling of Ships (HKC) and the Basel Convention develop standards and expectations at the international level for worker safety and environmental conditions [8]. The ILO guidelines are designed to assist shipbreakers and competent authorities in applying the relevant provisions of ILO standards, codes of practice, and other directives on occupational safety, health, and working conditions, and other relevant international organizations' provisions tools in a manner aimed at gradually improving them. Furthermore, the IMO guideline 8 emphasizes worker's health and safety aspects, which are to be addressed before the recycling process [9]. National governments continue to be important actors for this sector, as they are responsible for implementing these international legal frameworks advocated by Global Governance on Ship Breaking [8].

Compared to the International Maritime Organization (IMO) regulations, the shipbreaking industry in Bangladesh lacks several areas, including having a safe recycling plan and environmental protections [10]. Moreover, working in ship-breaking yards is considered one of the highest-risk jobs, and there is no supervision body to enforce basic environmental safety standards to ensure worker protection [11]. Despite the elusive size of the industry and its significant impact, Bangladesh has no specific regulatory framework to monitor this ongoing environmental damage. While many international instruments regulate the global ship-breaking operation, Bangladesh has not incorporated any of them and has not developed comprehensive local legislation addressing these concerns. Furthermore, Bangladesh has only ratified category or sector-specific international conventions on occupational health and safety of the International Labor Organization (ILO), and not yet the international labor standards policy, namely the Promotional Framework for Occupational Safety and Health Convention, 2006 (No. 187) and the Occupational Safety and Health Convention, 1981 (No. 155). In addition, the international standard ISO 45001 on occupational health and safety management systems is not well known.

Consequently, workers are often exposed to occupational risks that have significant adverse effects on human health and the environment. The Government of Bangladesh is trying to develop some regulatory guidelines. However, these initiatives are either biased or insufficient to deal with the country's industrial driving force and environmental drive [9].

Moreover, workers in the ship-breaking industry are usually less concerned with development programs because they belong as a vulnerable part of society [12]. Considering all these facts, a distinct and balanced policy for sustainable ship-dismantling activities, comprehensive training for all employees, fire safety, and PPE (Personal Protective Equipment) should improve occupational health and safety issues. This type of research is urgently needed to assess the ship-breaking industry's diverse impacts on the worker's 
livelihoods, worker's health, and the local environment to protect the environment and implement sustainable ship-breaking policies for the industry's progression.

In recent years, the ship-dismantling industry has focused on its economic benefits without considering the environmental impacts, livelihoods, and health hazards. Various studies have been carried on ship recycling and its impact on the environment, current issues, future challenges, and prospects of shipbreaking industries in Bangladesh [3,6,13]. However, little information is available on the ship-breaking activities' livelihood and occupational health hazard condition of workers working in the ship-breaking industry [14-16]. Therefore, the study was conducted on the ship-breaking industry worker's community at Bhatiari to understand the 'workers' livelihood and occupational health hazard conditions. This study will help determine the policy option and development of workers' livelihood conditions and determine the policy options and development of the livelihood condition of workers and the country's economy.

\section{Materials and Methods}

\subsection{Location}

The study was conducted between June 2019 and September 2019 at Bhatiari (Ward 5 and 6) in Bangladesh's Chattogram region (Figure 1). The Bhatiari coastal area is located in the southeastern part of Bangladesh between latitudes $22^{\circ} 28^{\prime} \mathrm{N}$ and longitudes $91^{\circ} 43^{\prime} \mathrm{E}$. The total number of people living in these villages is about 7000, of which 3000 live on Ward no. 5 and the remaining 4000 live on Ward no. 6.

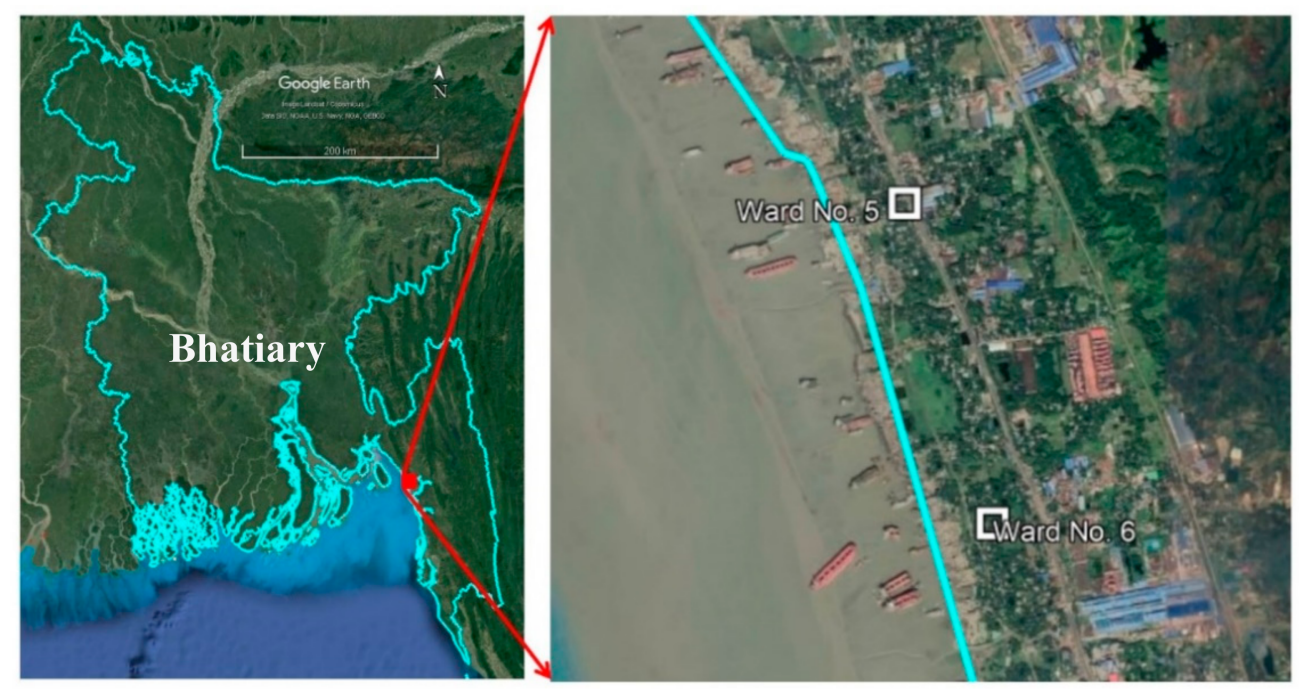

Figure 1. Map of the study area (Google Map) and Individual interviewee.

\subsection{Data Collection Method}

Both qualitative and quantitative data were collected through a semi-structured survey with local ship-breaking industry workers. All data were collected from 128 randomly selected ship-breaking industry workers using various data collection tools such as individual interviews, 15 key informant interviews (KIIs), and five focus group discussions (FGDs).

\subsubsection{Individual Interview}

A semi-structured questionnaire was developed to collect data on the livelihood and health hazards of the ship-breaking industry. Since the males worked mainly at the ship-breaking yard, the authors conducted individual interviews with the male workers (Figure 2). A total of 128 individual interviews were conducted during the survey period. Moreover, the convenience sampling method was also applied during the interview. Convenient sampling is a type of sampling in which a sample is taken from the population close to the hand. 

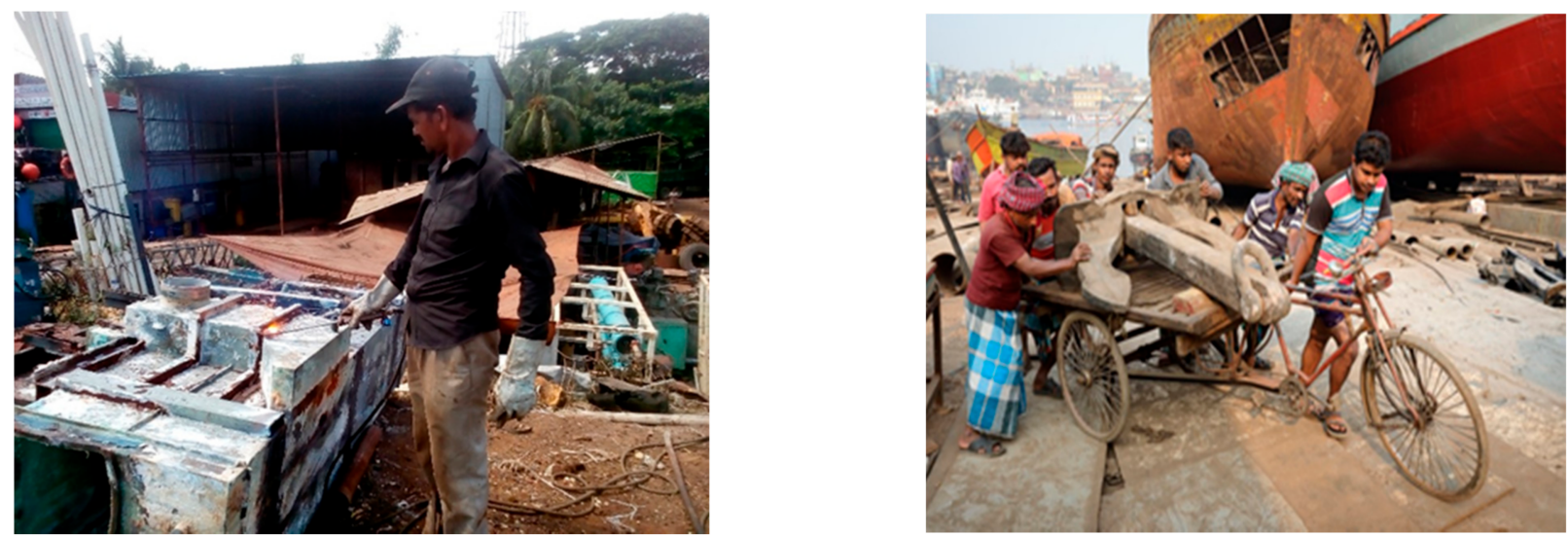

Figure 2. Ship-breaking workers engaged in ship dismantling and carrying objects.

\subsubsection{Focus Group Discussion}

A total of 5 focus group discussions were conducted in all study areas. The survey was carried out in several groups of 6 to 8 people. The duration of FGD was 20 to $30 \mathrm{~min}$.

\subsubsection{Livelihood Index Analysis}

To analyze the livelihood index, 20 indicators of livelihood capitals were considered. Four indicators were under human capital; six were physical, four natural, three financial, and three social capitals. Data were calculated by summing the score obtained from the selected indicators using three rating scales: $1=$ low, $2=$ medium, and $3=$ high. Secondary data were mainly collected from different scholarly articles and relevant literature. All data were analyzed using Microsoft Excel 2016.

The formula applied to calculate the livelihood index was:

Total score obtained by the respondent under the five

$$
\text { Livelihood Index }=\frac{\text { capitals of livelihood }}{\text { Maximum possible score of all the five capitals }} \times 100
$$

Livelihood indicators of five livelihood assets (i.e., human, physical, natural, financial, and social assets) for the selected community have also been considered in the study. So, it is essential to identify various components for each capital that positively or negatively impact entrepreneurship development, presented in detail in Table 1.

Table 1. Selected indicators of livelihood capitals for the ship-breaking yard workers' communities.

\begin{tabular}{lll}
\hline Types of Capitals & Measuring Indicators of Livelihood Capitals \\
\hline 1. Human capital & $\begin{array}{l}\text { Education, training facilities, working experience, nutritious } \\
\text { food consumption. }\end{array}$ \\
\hline 2. & Physical capital & $\begin{array}{l}\text { Housing condition, water facilities, sanitation, agricultural } \\
\text { equipment, livestock and poultry ownership, road structure. }\end{array}$ \\
\hline 3. & Natural capital & Land ownership, sources of water, and access to the forest. \\
\hline 4. Financial capital & Credit facilities, savings, and household income. \\
\hline $5 . \quad$ Social capital & Good relation with yard owner, good relation with relatives, \\
& & participation in a social gathering. \\
\hline
\end{tabular}


Moreover, a risk assessment (Figure 3) has been developed based on a matrix of risk crossing the probability of an event for a phenomenon and the relative severity. The risk comes from the multiplication of the probability and the severity (Table 2).

\begin{tabular}{|l|l|l|l|l|}
\hline 4 & 4 & 8 & 12 & 16 \\
\hline 3 & 3 & 6 & 9 & 12 \\
\hline 2 & 2 & 4 & 6 & 8 \\
\hline 1 & 1 & 2 & 3 & 4 \\
\hline & 1 & 2 & 3 & 4 \\
\hline
\end{tabular}

\begin{tabular}{|l|l|}
\hline Risk & Rating \\
\hline Extreme risk & $09-16$ \\
\hline High risk & $\mathbf{0 6 - 0 8}$ \\
\hline Moderate risk & $\mathbf{0 3 - 0 4}$ \\
\hline Low risk & $\mathbf{0 1 - 0 2}$ \\
\hline
\end{tabular}

Figure 3. The risk level and risk matrix.

Table 2. Degree of probability, the severity of consequences, and rating.

\begin{tabular}{cccc}
\hline Degree of Probability & Rating & Severity of Consequences & Rating \\
\hline Frequent, once per week & 4 & Major & 4 \\
\hline $\begin{array}{c}\text { Occasional, the occurrence of } \\
\text { risk is once a month }\end{array}$ & 3 & Serious & 3 \\
\hline $\begin{array}{c}\text { Seldom, the occurrence of } \\
\text { risk is once in 3-6 months }\end{array}$ & 2 & Minor & 2 \\
\hline $\begin{array}{l}\text { Unlikely, the occurrence of } \\
\text { risk is once in a year or more }\end{array}$ & 1 & Incidental & 1 \\
\hline
\end{tabular}

\section{Results}

\subsection{Demographic Status of Shipbreaking Industry Workers}

Table 3 showed that most of the workers in both villages were daily laborers or had no jobs in the past. At ward no. 5, 35.29\% were daily laborers, followed by $28.57 \%$ at ward. no. 6. Besides that, at Bhatiari ward no. 5, 1.96\%, 19.61\%, 9.80\%, 1.97\%, $15.69 \%$ were drivers, fishermen, small businessmen, students, a rickshaw puller, respectively. At Bhatiari ward no. 6, drivers, fishermen, small businessmen, students, and rickshaw pullers were $7.79 \%, 20.78 \%, 6.49 \%, 2.60 \%$, and $23.38 \%$, respectively. Moreover, $15.69 \%$ and $10.39 \%$ of workers had no job at wards 5 and 6 in the past.

Table 3. Demographic profile ship-breaking yard workers at Bhatiari.

\begin{tabular}{cccc}
\hline Content & Level of Content & Ward No. 5 & Ward No. 6 \\
\hline & & Frequency (\%) & Frequency (\%) \\
\hline Gender & Male & 100 & 100 \\
\hline Marital Status & Female & 0 & 0 \\
\hline \multirow{2}{*}{$\begin{array}{c}\text { The main occupation of } \\
\text { the workers }\end{array}$} & Married & 63 & 58 \\
\hline & Single & 37 & 42 \\
\hline & Gune operator & 39.21 & 14.28 \\
\hline & Cutter & 1.96 & $0.00 \%$ \\
\hline & Loader & 9.8 & 6.4935 \\
\hline & Helper & 58.82 & 53.24 \\
\hline
\end{tabular}


Table 3. Cont.

\begin{tabular}{cccc}
\hline Content & Level of Content & Ward No. 5 & Ward No. 6 \\
\hline Alternative occupation & & Frequency (\%) & Frequency (\%) \\
\hline & Day labor & 35.29 & 28.57 \\
\hline & Driver & 1.96 & 7.79 \\
\hline Fisherman & 19.61 & 20.78 \\
\hline Small businessman & 9.80 & 6.49 \\
\hline Student & 1.96 & 2.60 \\
\hline Rickshaw puller & 15.69 & 23.38 \\
\hline & No job & 15.69 & 10.39 \\
\hline
\end{tabular}

3.2. Livelihood Capitals of the Workers

3.2.1. Human Capitals

Age Distribution Patterns

The majority of the respondents $(31.37 \%)$ in Bhatiari ward no. 5 were in the age group of $36-40$ years, and $37.66 \%$ of the respondents in Bhatiari ward no. 6 were in the age group of 26-30 years representing a physically strong workforce working in the ship-breaking industry (Figure 4).

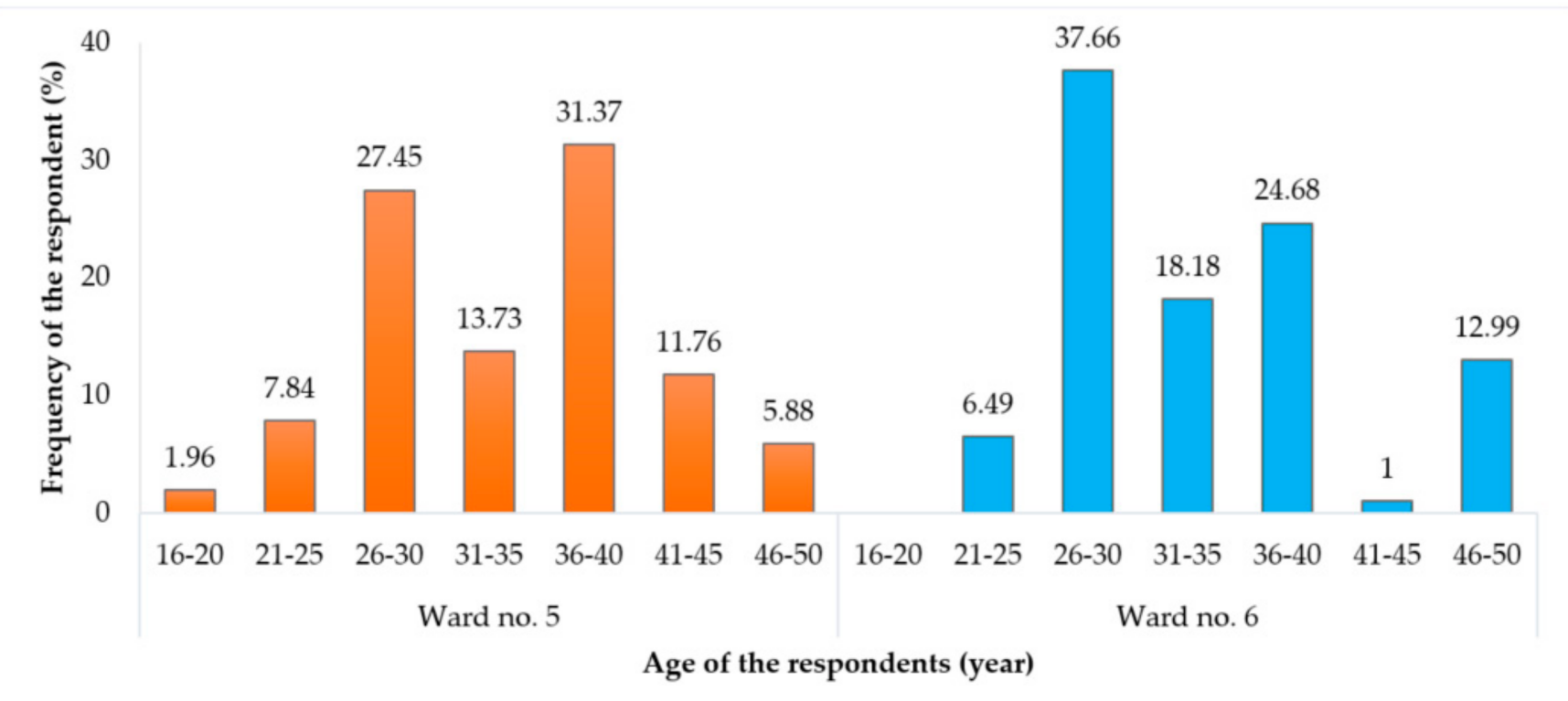

Figure 4. Age distribution status of ship-breaking yard workers at Bhatiari.

Family Type

According to the results, $70.59 \%$ of workers in ward no. 5 lived in nuclear families, and $29.41 \%$ lived in joint families, while in ward no. 5, 75.32\% of workers belonged to nuclear families, and the remaining $24.68 \%$ were joint families (Figure 5). 


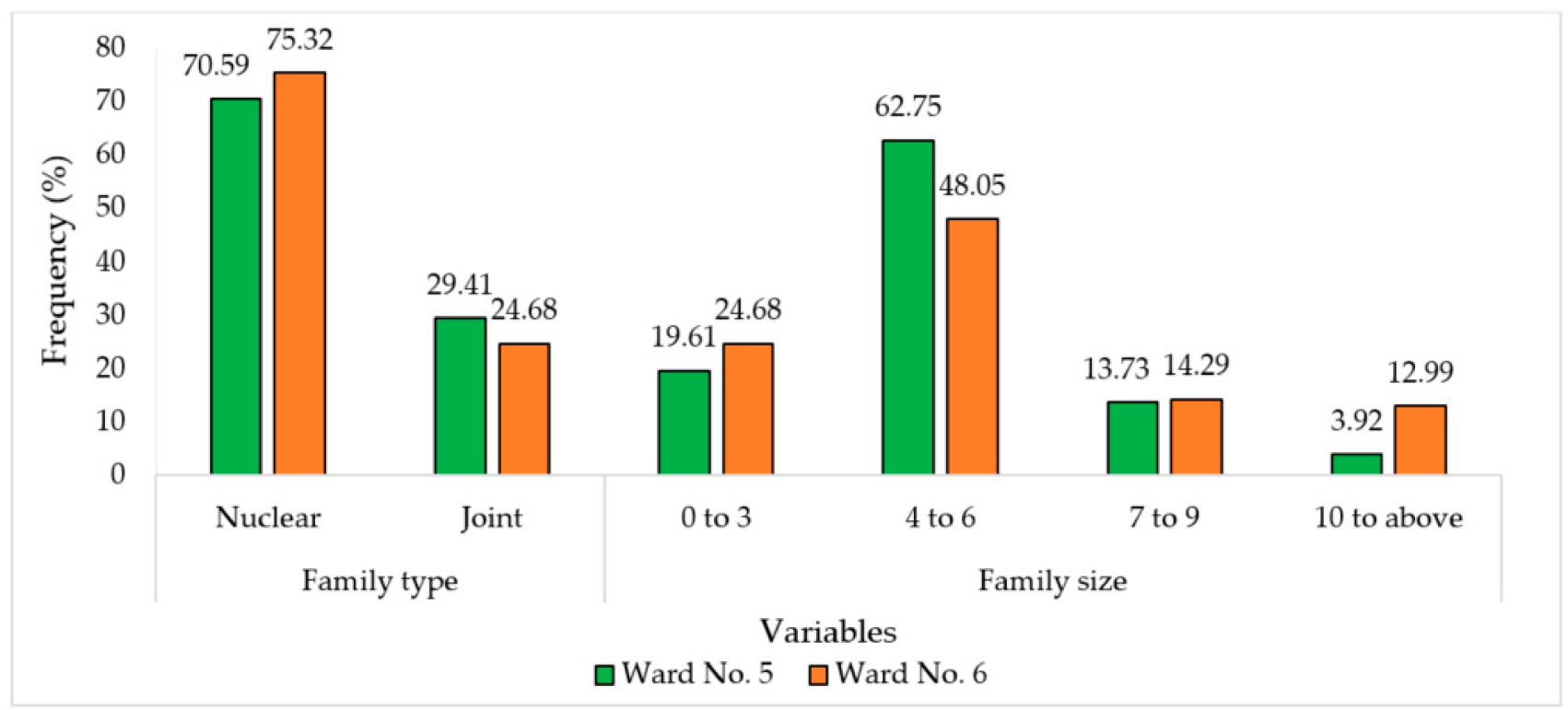

Figure 5. Family type and size of ship-breaking yard workers at Bhatiari.

Educational Qualification

The study revealed that $47.06 \%$ of Bhatiari ward workers no. 5 had no formal education, $25.49 \%$ can only sign, $21.57 \%$ were primarily passed, and $5.88 \%$ had secondary education. These percentages at ward no. 6 were $44.16 \%, 32.47 \%, 23.38 \%$, and $1.30 \%$, respectively (Figure 6).

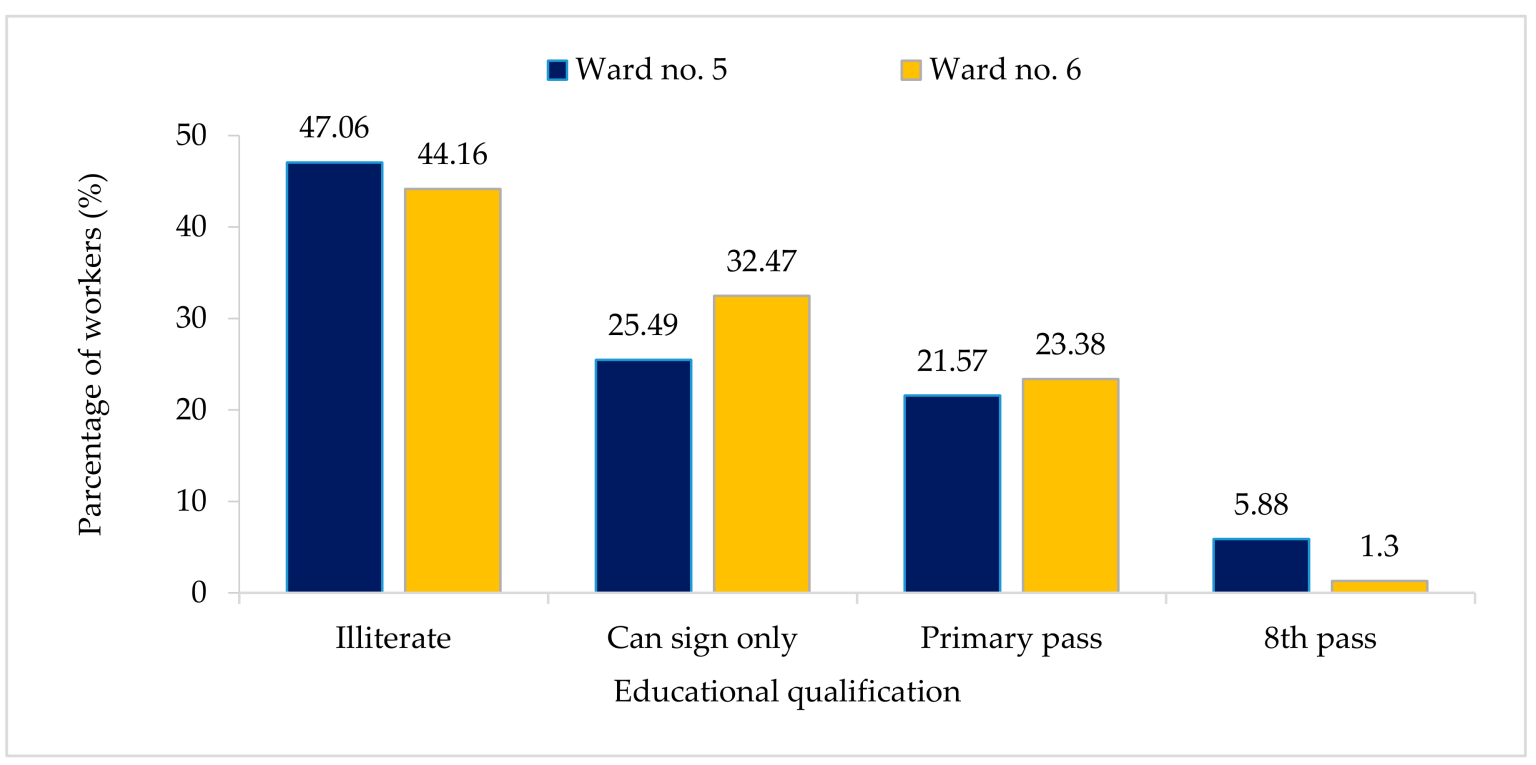

Figure 6. Educational status of ship-breaking yard workers at Bhatiari.

Home Division of the Workers

Workers from different parts of Bangladesh, including Barisal, Rajshahi, and Sylhet, Bogra, earn a living. More than half of ward 5 (54.90\%) workers had homes in and around the ship-breaking yards of Chattogram, while $29.87 \%$ of workers in ward 6 were from Khulna (Figure 7). 


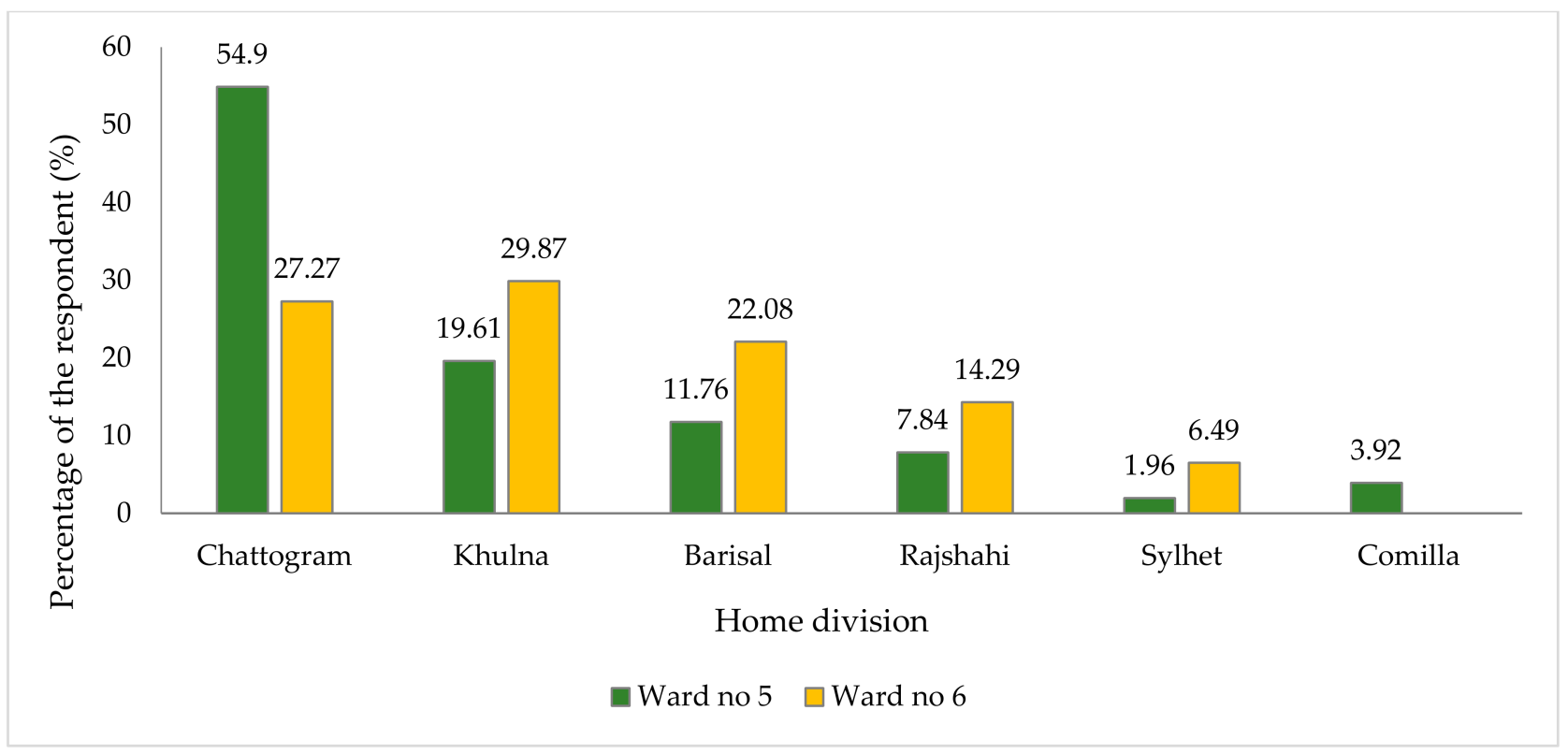

Figure 7. Home division of ship-breaking yard workers at Bhatiari.

Working Hours and Experience of the Workers

Working in a ship-breaking yard is arduous labor, and the workers had to work in very long shifts. The results showed that most workers (31.37\%) at ward no. 5 work more than $12 \mathrm{~h}$ a day, and $31.17 \%$ of workers at ward no. 6 work $11-12 \mathrm{~h}$ in a day (Figure 6). Moreover, workers have a wide range of experience from less than a year to above 21 years. More than one-third of the workers from Bhatiari wards no. 5 and 6 had experience of 1 to 6 years. Only 2.92\% workers from ward no. 5 and $6.49 \%$ of workers from ward no. 6 had experience above 21 years (Figure 8).

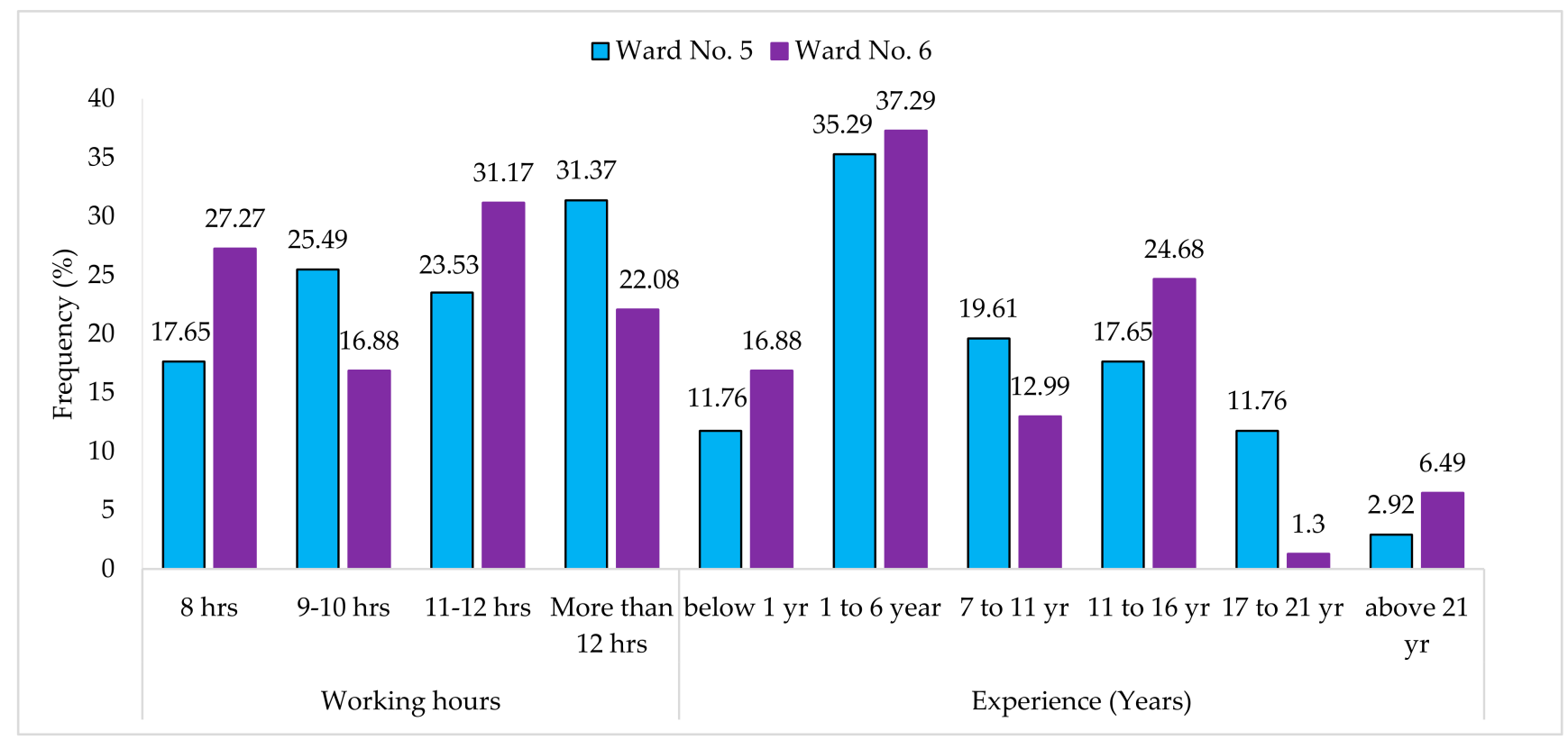

Figure 8. Working hours and experience of ship-breaking yard workers at Bhatiari. 


\subsubsection{Physical Capital}

Housing Condition

Housing conditions of a community indicate the level of well-being or economic status of the people. The workers' housing situation was relatively poor, where most of the houses were built with straw roofs and bamboo with mud floors. The survey showed that $70.59 \%$ of houses at Bhatiari ward no. 5 and $66.23 \%$ of houses at Bhatiari ward no. 6 had a straw roof and bamboo (Figure 9).

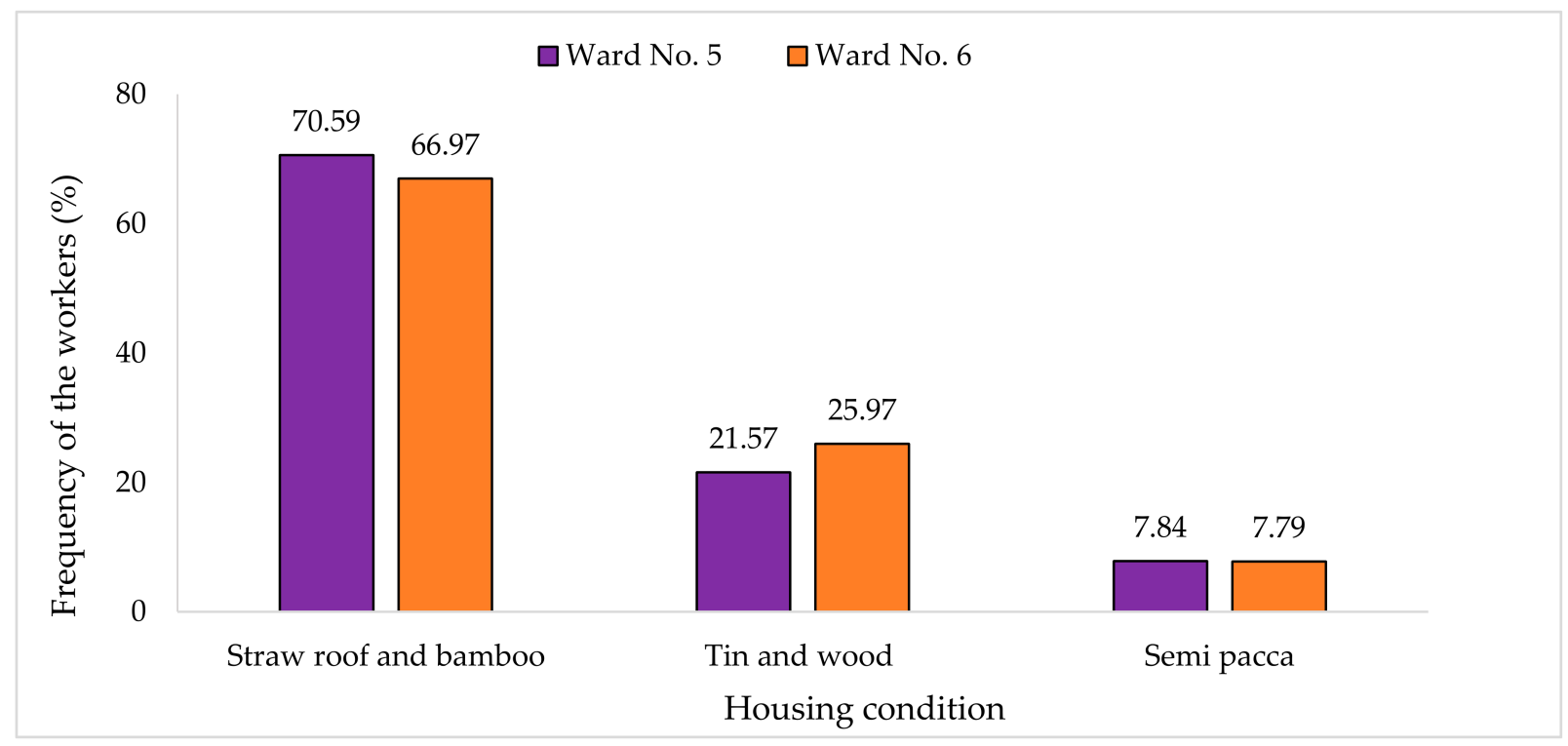

Figure 9. Housing condition of ship-breaking yard workers at Bhatiari.

Drinking-Water Sources

Access to sanitary, clean, and safe drinking water is regarded as the essential fundamentals in society. The survey results showed that more than $80 \%$ of the Bhatiari ward workers no. 5 and 6 use tubewell as their primary source of water (Figure 10), while 9.80\% of people of ward no. 5 and $12.99 \%$ of people of ward no. 6 use pond water.

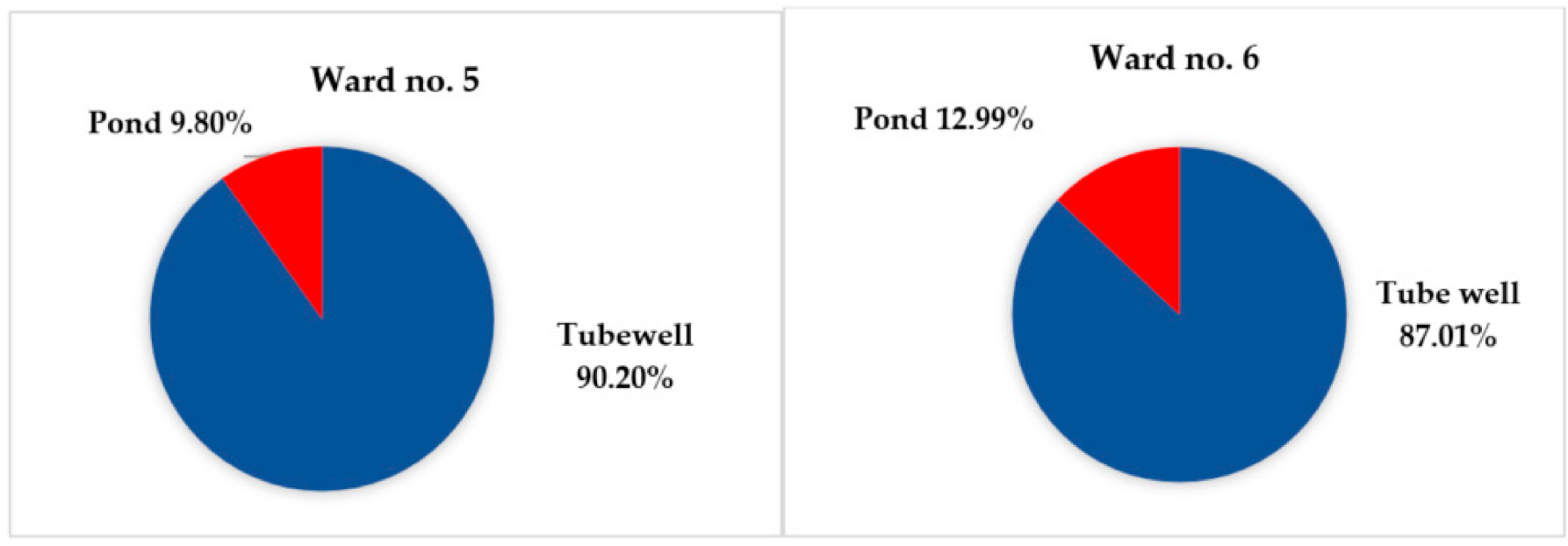

Figure 10. Drinking water sources of ship-breaking workers at Bhatiari.

Sanitation and Working Conditions

Ship-breaking workers were found to work hard all day in a hostile and dangerous environment in a limited facility. In sanitation, $43.14 \%$ of workers in ward no. 5 stated the 
sanitary facility was awful, while $41.56 \%$ of workers in ward no. 6 stated the condition was not good. In sanitary facilities, $43.14 \%$ of workers in Ward no. 5 said the facilities were inferior, and $41.56 \%$ of the workers in ward no. 6 stated the condition was not good. The majority of workers (52.94\% in ward 5 and $40.26 \%$ in ward 6) said that working conditions at the Bhatiari ship-breaking yards were not good (Figure 11).

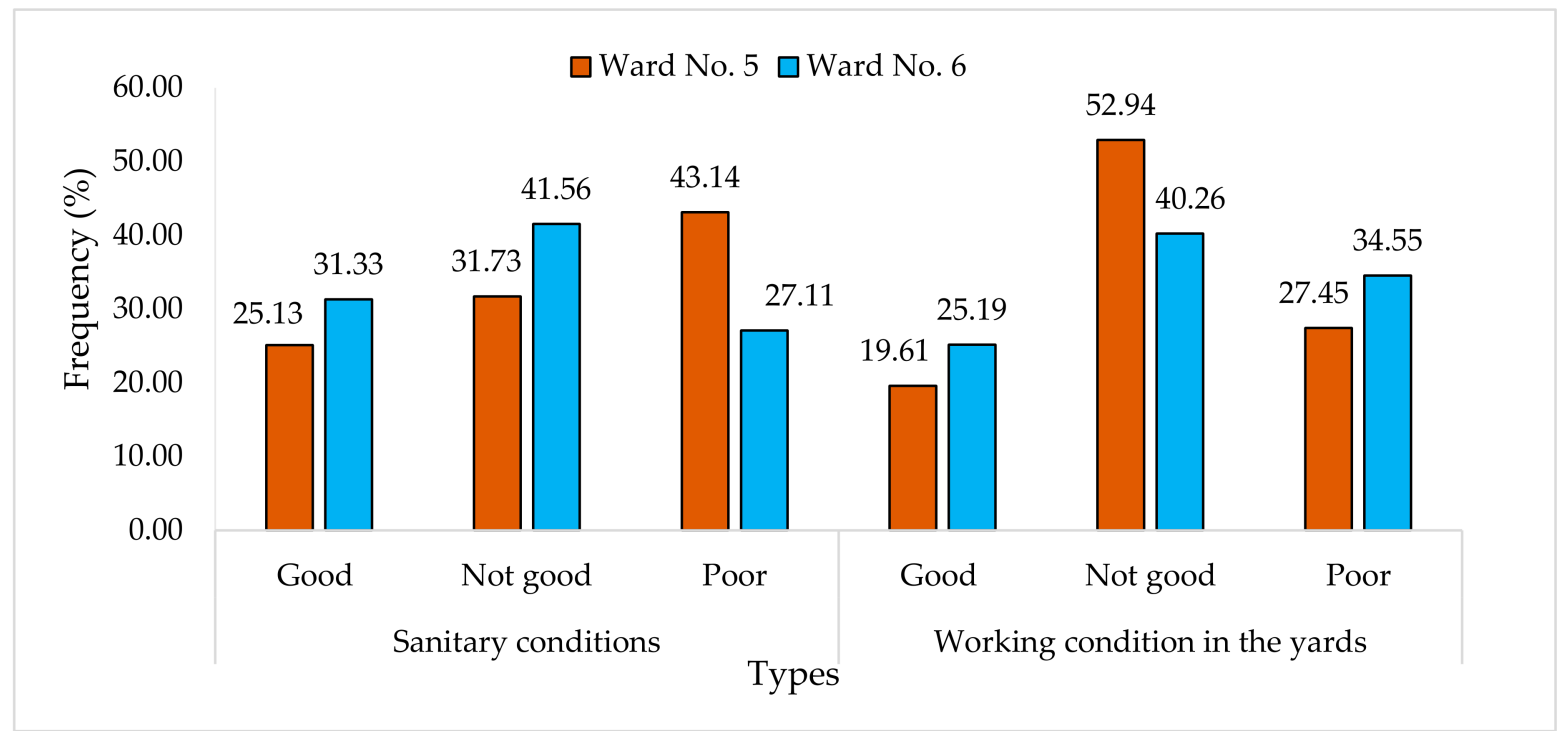

Figure 11. Sanitation and working conditions of ship-breaking workers at Bhatiari.

\subsubsection{Financial Capital}

Income

This present study indicates that workers at both Bhatiari wards no. 5 and 6 have a meager annual income. Most workers (47.06\% at ward no. 5 and $649.35 \%$ at ward no. 6 ) earned USD 832-951 per year, whereas 3.92\% of workers in ward 5 and $9.09 \%$ of workers in ward six earned above USD 1188 per year (Figure 12).

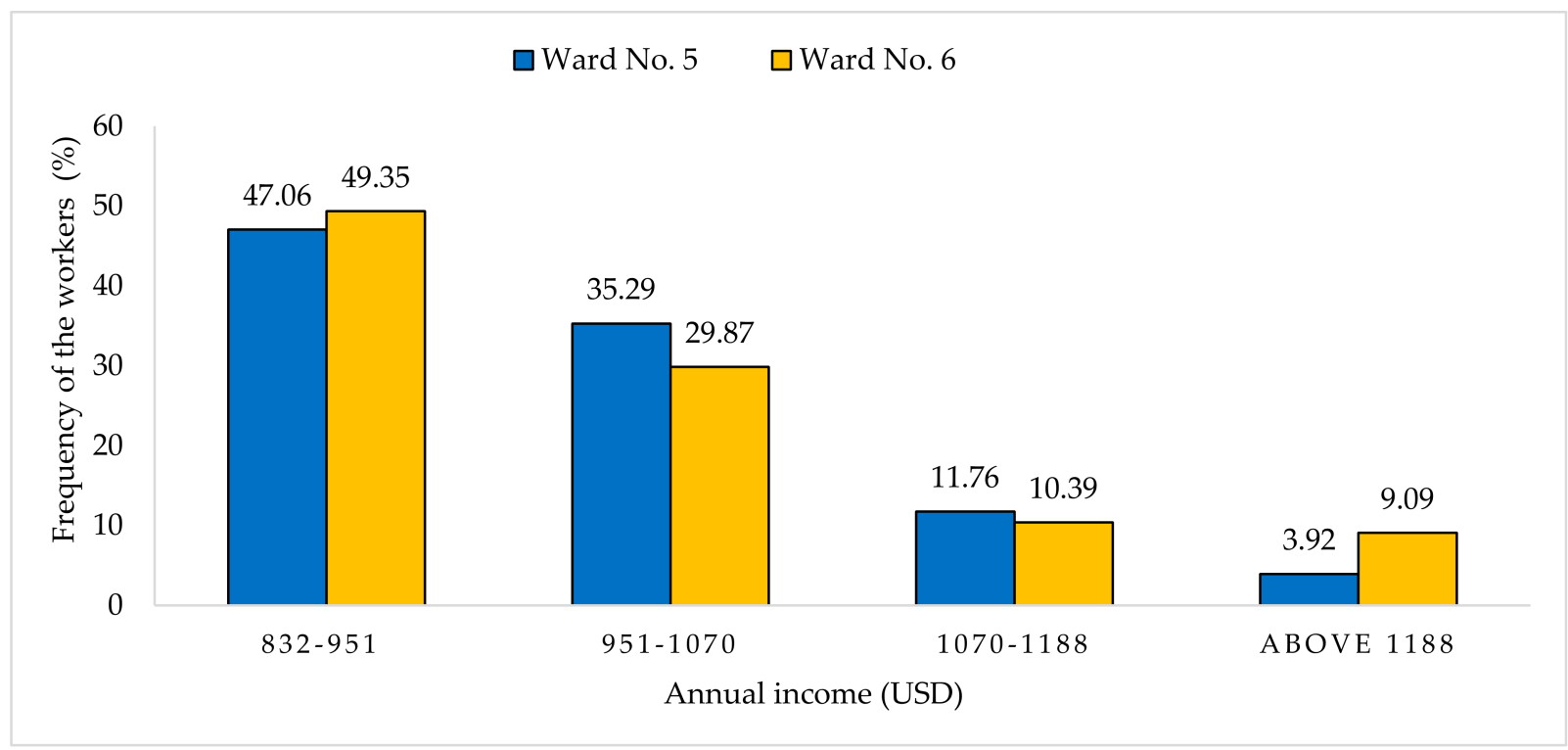

Figure 12. Annual income percentage of ship-breaking yard workers at Bhatiari. 


\section{Credit Access}

As a result of low income, the ship-breaking industry workers must lend money from various sources. The findings revealed that $33.33 \%$ of Bhatiari ward no. 5 employees take a loan from their relatives, $15.69 \%$ from friends, and $47.06 \%$ from Non-Governmental Orgaizations (NGOs) (Figure 13). At ward no. 6, this percentage was $28.57 \%, 25.97 \%$, and $38.96 \%$. In addition to this, $2.60 \%$ of the workers in ward six also reported taking a loan from the bank.

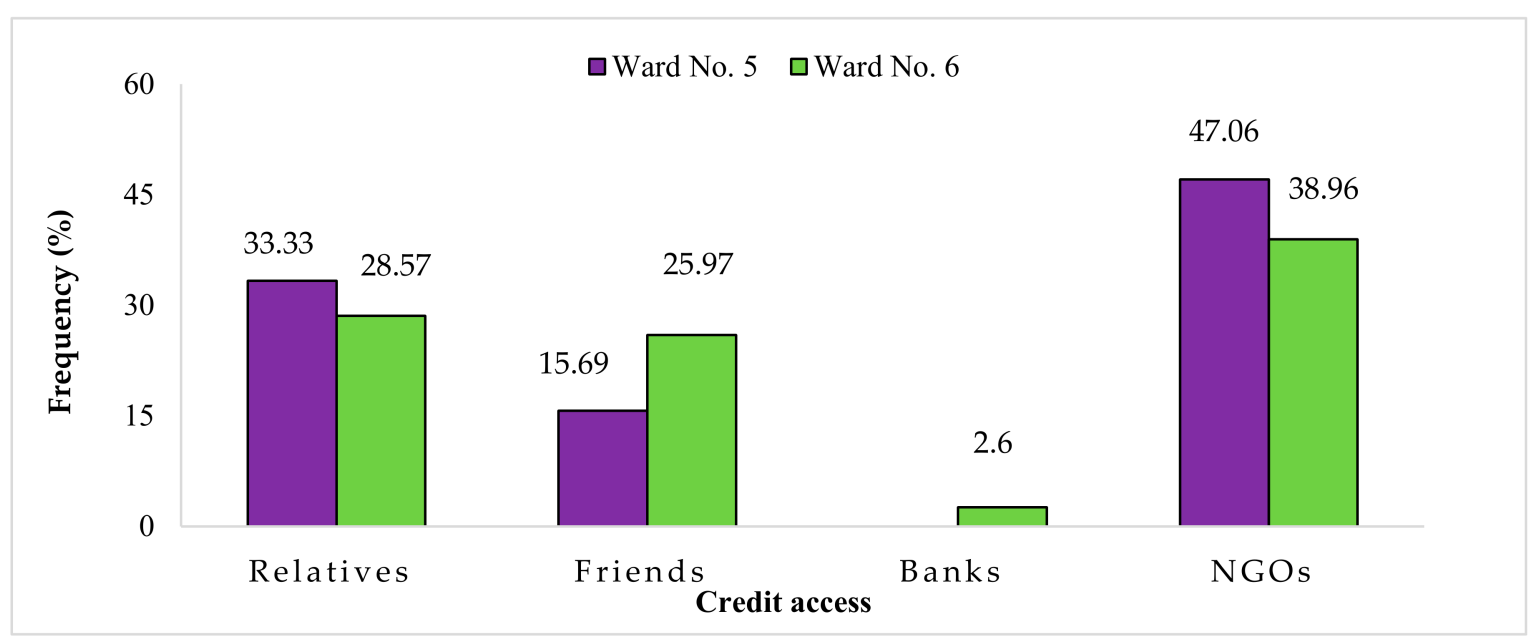

Figure 13. Percentage of credit source of ship-breaking yard workers at Bhatiari.

\subsection{Occupational Health Hazards}

Table 4 shows that $64.71 \%$ of workers have access to natural resources at Bhatiari ward no. 5 , and at ward no. 6 , the percentage was $59.74 \%$. Though the workers do not actively engage in agricultural work, their wives tend to grow vegetables in the yard. The results showed that only $27.45 \%$ of workers at Bhatiari ward no. 5 and $37.66 \%$ of workers at ward no. 6 have agricultural land (Table 4). The present study showed that $45.10 \%$ of workers at ward no. 5 and at Bhatiari ward no. 6 , only $33.77 \%$ of workers, have access to forest resources.

Table 4. The natural capital of ship-breaking yard workers at Bhatiari.

\begin{tabular}{ccccc}
\hline \multirow{2}{*}{ Natural Capital } & \multicolumn{2}{c}{ Ward No 5 } & \multicolumn{2}{c}{ Ward No 6 } \\
& Yes & No & Yes & No \\
\hline Access to natural resources & $64.71 \%$ & $35.29 \%$ & $59.74 \%$ & $38.96 \%$ \\
Agricultural land & $27.45 \%$ & $72.55 \%$ & $37.66 \%$ & $61.04 \%$ \\
Source of water & $29.41 \%$ & $70.59 \%$ & $29.87 \%$ & $70.13 \%$ \\
Forest access & $45.10 \%$ & $52.94 \%$ & $33.77 \%$ & $66.23 \%$ \\
\hline
\end{tabular}

\subsection{Livelihood Index}

To achieve positive livelihood outcomes, a variety of livelihood capitals are necessary. The livelihood index of ship-breaking industry workers was analyzed by considering capital criteria, encompassing five components: Human, financial, natural, social, and physical capital. Table 4 found that the livelihood index of both wards was more or less similar, but the change in livelihood capital was different. At ward no. 5, the change in physical livelihood was $8.52 \%$, whereas at ward no. 6 , it was $22.14 \%$ (Table 5). 
Table 5. Livelihood index analysis of ship-breaking yard workers at Bhatiari.

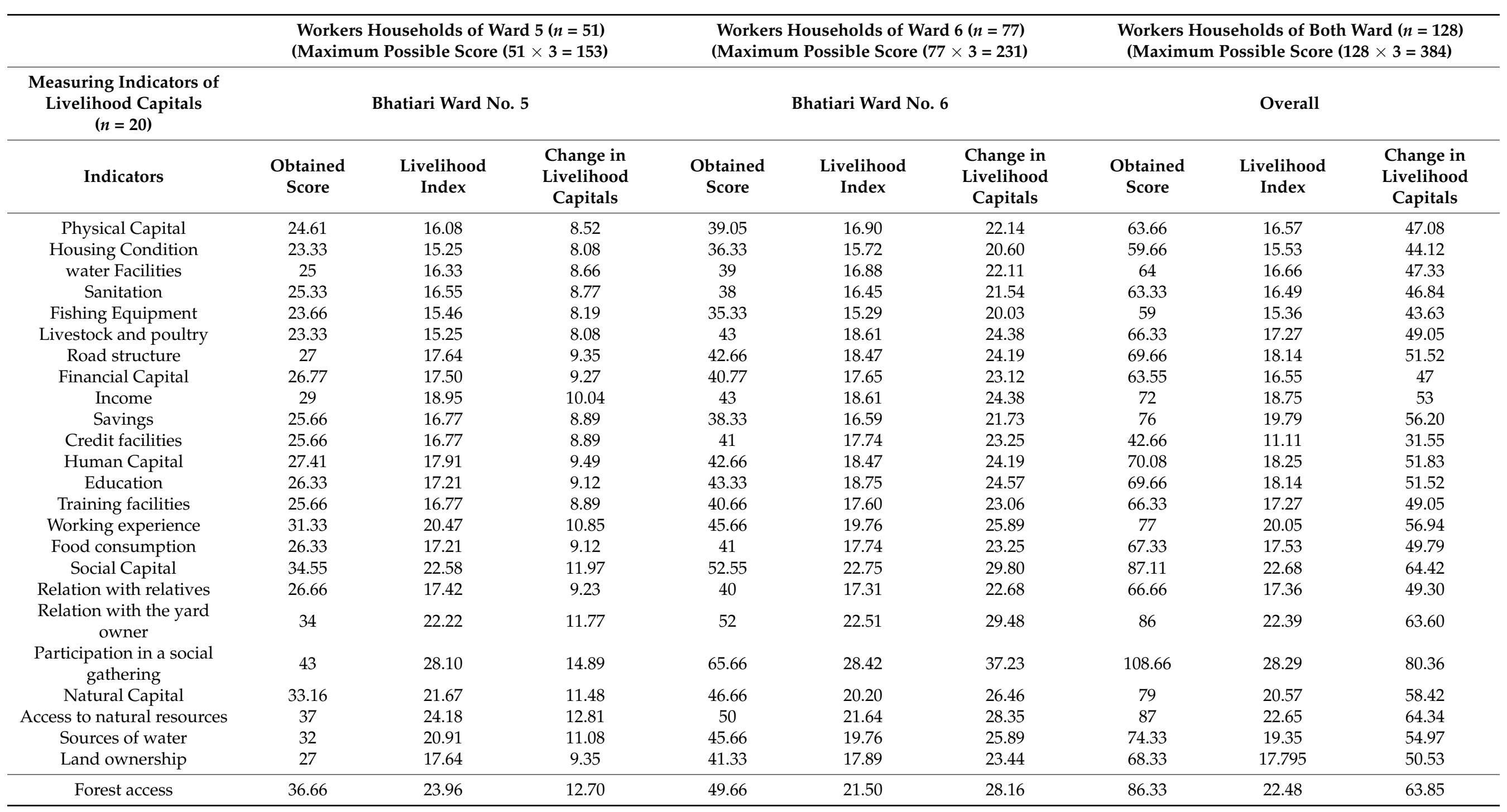


Change in financial capital at ward no. 5 was $9.27 \%$, and $23.12 \%$ was at ward no. 6 . Change in human capital at wards no. 5 and 6 were $9.49 \%$ and $24.19 \%$, respectively. It was found that change in social and natural capital at ward no. 5 was $11.97 \%$ and $11.48 \%$, whereas at ward no. 6 , it was $29.80 \%$ and $26.46 \%$, respectively (Figure 14 ).

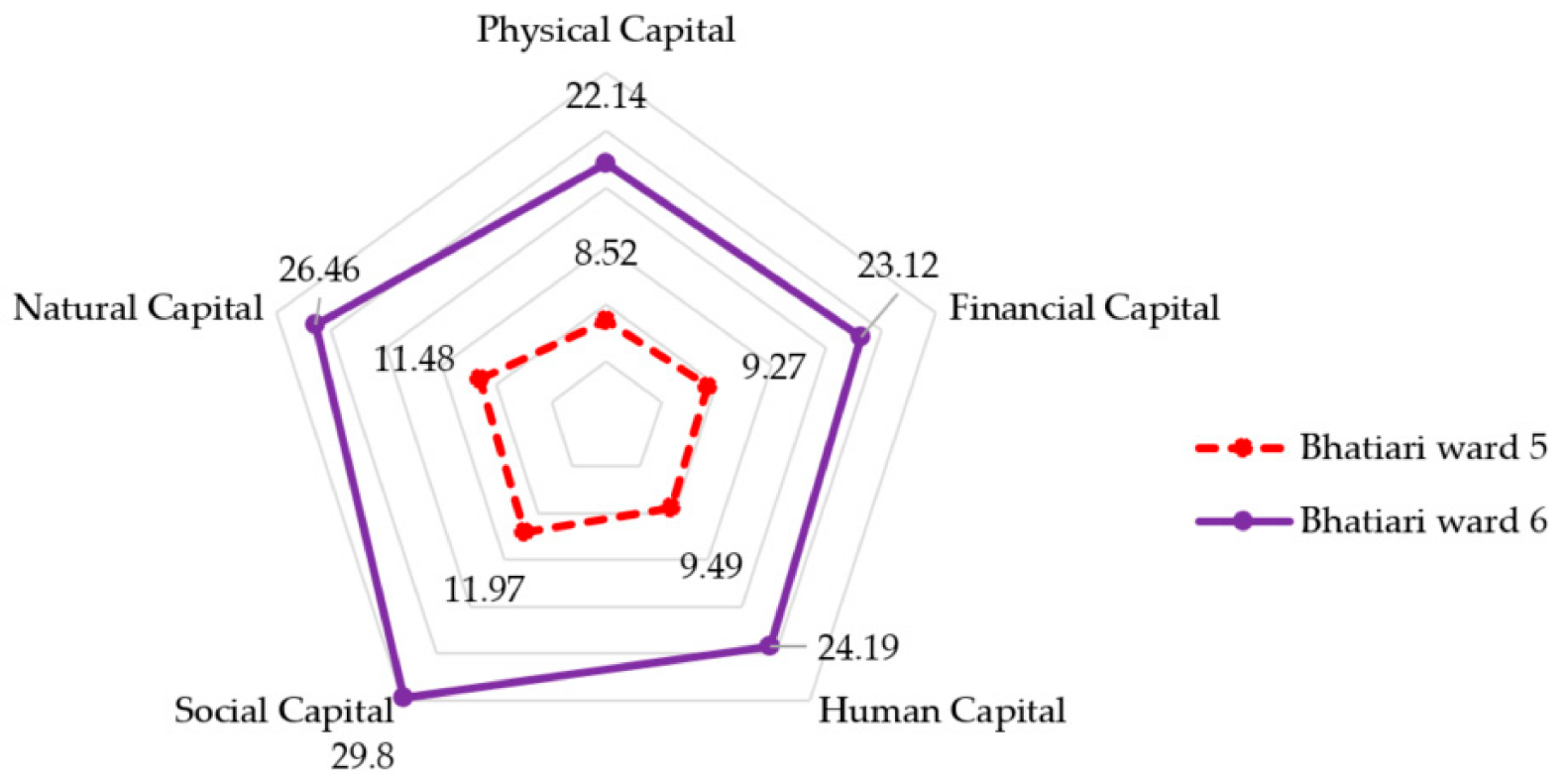

Figure 14. Change in livelihood capital of ship-breaking yard workers at Bhatiari.

\subsection{Occupational Health Hazards}

Physical Injury and Protective Gear

Physical injury is prevalent amongst the workers in ship-breaking yards due to a lack of safety measures. Protective gear such as gloves, sunglasses, and helmets are essential in working at the ship and the ship-breaking yard. However, the study found that nearly half of the workers do not wear any type of protective gear (Figure 12). Figure 12 reflected that $62.75 \%$ of workers at ward no. 5 have faced physical injury once or multiple times, and at ward no. 6, the percentage was $64.94 \%$ (Figure 15).

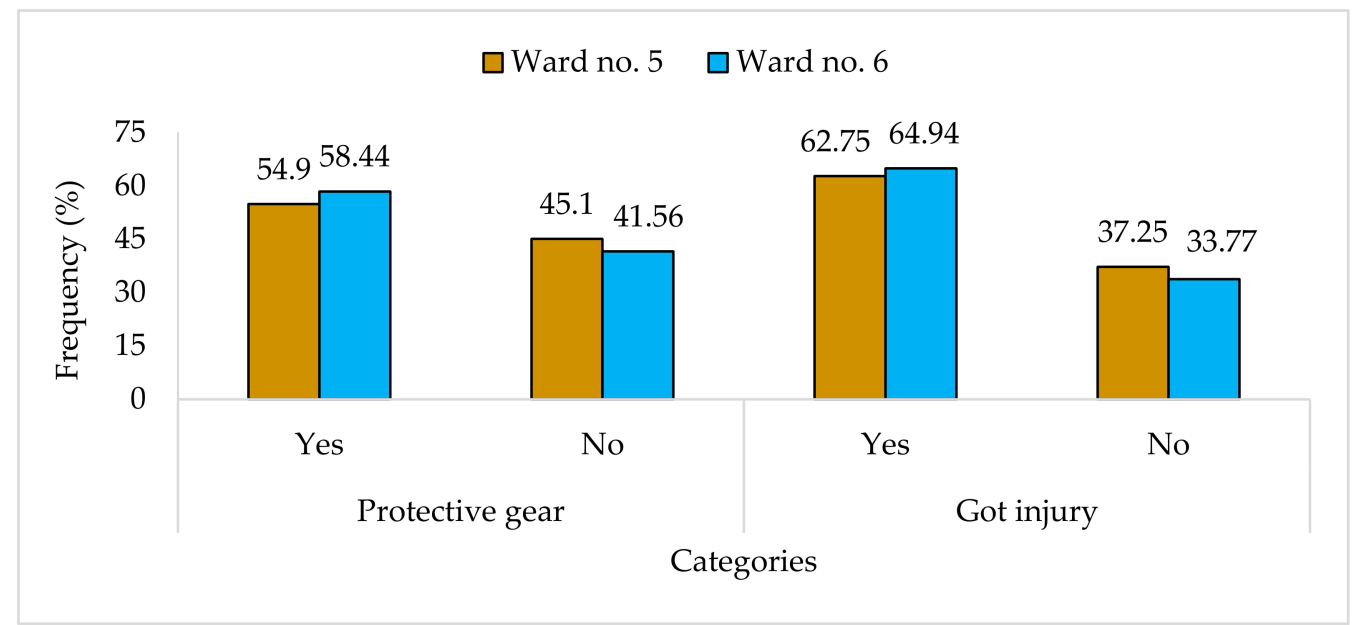

Figure 15. Percentage of workers with protective gear and that suffered injuries in ship-breaking yards at Bhatiari. 


\subsection{Physical Problems}

Workers have faced many types of physical problems during working in the shipbreaking yard. Most of the problems include respiration, skin, and muscle as they must work too hard and work with fire. The result shows that at Bhatiari ward no. 5, 23.53\% of workers have eye redness, and at Bhatiari ward no. 6, the percentage was $33.77 \%$ (Table 6). It was also found that most of the workers (27.45\%) at Bhatiari ward no. 5 and $23.38 \%$ of ward no. 6 have blurred vision (Table 6), which may be due to use fire to cut off the metal plates of the ship. Moreover, they were also exposed to the heat and smoke that also caused breathing problems. The result showed that $19.61 \%$ and $29.87 \%$ of the workers at Bhatiari ward no. 5 and 6 had asthma, followed by $35.29 \%$ and $31.17 \%$ with chest pain. In the case of abdominal problems, it was mainly related to hygiene and workers' nutritional diet. Besides, both wards face various abdominal problems such as nausea, vomiting, abdominal pain, and gastric. Furthermore, $9.80 \%$ of workers in ward no. 5 and $12.98 \%$ of workers in ward no. 6 of Bhatiari reported having urination problems. Ship-breaking yard workers are exposed to dust and fumes, which also cause skin problems. In addition, $13.73 \%$ and $19.48 \%$ of Bhatiari employees of wards no. 5 and 6 reported having a lesion in their bodies. Most of the workers at both wards did not have a proper meal in a day. These caused nutritional problems in their body. In the survey, $56.86 \%$ of workers at ward no. 5 reported that they felt weakness during work. Moreover, $58.44 \%$ of workers at ward no. 6 reported the same problem.

Table 6. Different physical problems faced by the ship-breaking yard workers at Bhatiari.

\begin{tabular}{|c|c|c|c|}
\hline Physical Problems & Ward No. 5 & Ward No. 6 & Overall \\
\hline \multicolumn{4}{|l|}{ Eye problem } \\
\hline Redness & $23.53 \%$ & $33.77 \%$ & $29.69 \%$ \\
\hline Tearing & $3.92 \%$ & $0.00 \%$ & $1.56 \%$ \\
\hline Burning sensation & $17.65 \%$ & $19.48 \%$ & $18.75 \%$ \\
\hline Blurring vision & $27.45 \%$ & $23.38 \%$ & $25.00 \%$ \\
\hline \multicolumn{4}{|l|}{ Respiratory Problem } \\
\hline Asthma & $19.61 \%$ & $29.87 \%$ & $25.78 \%$ \\
\hline Pneumonia & $9.80 \%$ & $16.88 \%$ & $14.06 \%$ \\
\hline Cough & $17.65 \%$ & $14.29 \%$ & $15.63 \%$ \\
\hline Chest pain & $35.29 \%$ & $31.17 \%$ & $32.81 \%$ \\
\hline \multicolumn{4}{|l|}{ Abdominal Problem } \\
\hline Anorexia & $9.80 \%$ & $12.99 \%$ & $11.72 \%$ \\
\hline Nausea & $23.53 \%$ & $16.88 \%$ & $19.53 \%$ \\
\hline Vomiting & $15.69 \%$ & $20.78 \%$ & $18.75 \%$ \\
\hline Abdominal pain & $31.37 \%$ & $31.17 \%$ & $31.25 \%$ \\
\hline Gastric & $25.49 \%$ & $20.78 \%$ & $22.66 \%$ \\
\hline \multicolumn{4}{|l|}{ Urinary problem } \\
\hline Dysuria & $9.80 \%$ & $12.98 \%$ & $11.72 \%$ \\
\hline \multicolumn{4}{|l|}{ Muscle problem } \\
\hline Backache & $15.69 \%$ & $23.38 \%$ & $20.31 \%$ \\
\hline Neck ache & $23.53 \%$ & $33.77 \%$ & $29.69 \%$ \\
\hline Knee joint pain & $17.65 \%$ & $10.39 \%$ & $13.28 \%$ \\
\hline \multicolumn{4}{|l|}{ Skin problem } \\
\hline Itching & $23.53 \%$ & $31.17 \%$ & $28.13 \%$ \\
\hline Lesion & $13.73 \%$ & $19.48 \%$ & $17.19 \%$ \\
\hline \multicolumn{4}{|l|}{ Nutritional problem } \\
\hline Vertigo & $11.76 \%$ & $12.99 \%$ & $12.50 \%$ \\
\hline Headache & $23.53 \%$ & $23.38 \%$ & $23.44 \%$ \\
\hline Weakness & $56.86 \%$ & $58.44 \%$ & $57.81 \%$ \\
\hline
\end{tabular}




\subsection{Risk Assessment of Ship-Breaking Yard Associated with the Operational Activity of Ship Dismantling}

The risk of ship-breaking yards associated with the operational activity of dismantling the once-beached scrap ship has been analyzed (Figure 15). The highest risk level was 12 , standard for most activities associated with cutting operation like storing cylinders, ignition and actual cutting processes, and storage of hazardous materials like oil, chemicals, asbestos, and sludge. Activities like cutting sheet, cylinder handling, oil transfers, and storage and preservation of glass wool had risk levels between 6 and 8, which are considered moderately high(Figure 16).

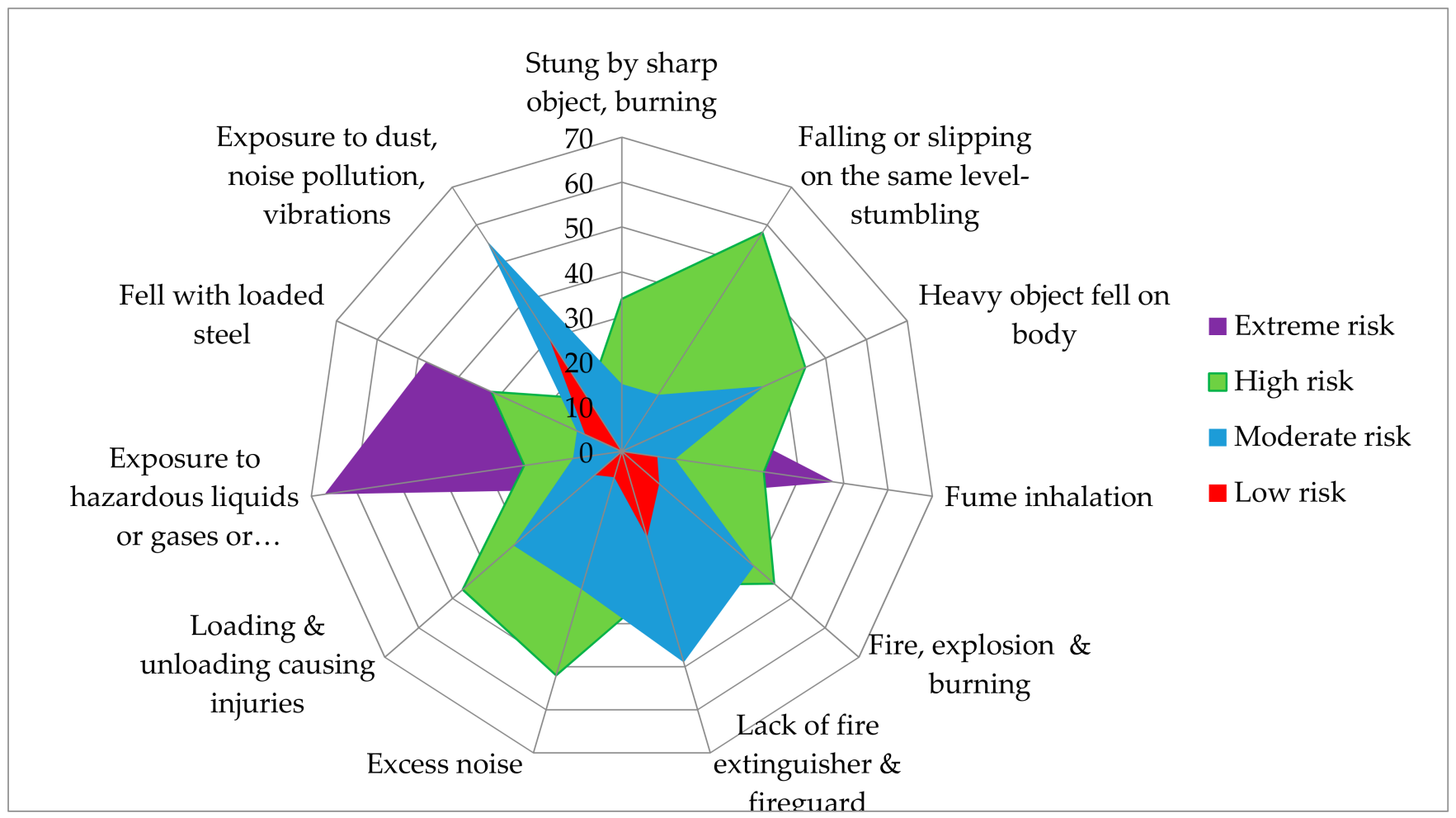

Figure 16. Radar chart for occupational health hazards of ship-breaking yard workers at Bhatiari.

Additionally, cable/electrical operations, pipe handling, and machinery dismantling had a comparatively lower risk of level 4 , followed by several other activities with a low-risk level of just 1 . The respondents expressed that the extensive risk control method needed to be implemented, especially during the high- and moderately high-risk activities, but were rarely done. Many workers were reported to have suffered from fatal injuries or loss of limbs/sensory organs due to risk level 6-12 activities (Table 7).

Table 7. Risk analysis of ship-breaking yard associated with the operational activity of ship dismantling.

\begin{tabular}{|c|c|c|c|c|c|c|}
\hline Operation & $\begin{array}{c}\text { Hazards } \\
\text { Description }\end{array}$ & Causal Risk Factor & Severity & Probability & Risk & Level of Risk \\
\hline $\begin{array}{c}\text { Materials } \\
\text { Dismantling }\end{array}$ & $\begin{array}{l}\text { Stung by sharp } \\
\text { object, Burning, } \\
\text { explosion, fire }\end{array}$ & $\begin{array}{l}\text { Pipe containing gases, } \\
\text { machinery dismantling }\end{array}$ & 2 & 3 & 6 & High risk \\
\hline Beaching & Health hazards & $\begin{array}{c}\text { Beaching \& } \\
\text { disembarking }\end{array}$ & 2 & 1 & 2 & Low risk \\
\hline Cutting operation & $\begin{array}{l}\text { Falling on the same } \\
\text { level-stumbling, } \\
\text { slipping }\end{array}$ & $\begin{array}{l}\text { Slipping on wet surfaces } \\
\text { or something laying or } \\
\text { fastening on the walking } \\
\text { surface }\end{array}$ & 3 & 2 & 6 & High risk \\
\hline
\end{tabular}


Table 7. Cont.

\begin{tabular}{|c|c|c|c|c|c|c|}
\hline \multirow[t]{8}{*}{ Operation } & $\begin{array}{c}\text { Hazards } \\
\text { Description }\end{array}$ & Causal Risk Factor & Severity & Probability & Risk & Level of Risk \\
\hline & $\begin{array}{c}\text { Hazardous } \\
\text { mechanical } \\
\text { situations due to } \\
\text { equipment }\end{array}$ & $\begin{array}{l}\text { Failure of machinery } \\
\text { and equipment }\end{array}$ & 2 & 4 & 8 & High risk \\
\hline & $\begin{array}{c}\text { Hazardous } \\
\text { substances and } \\
\text { wastes }\end{array}$ & $\begin{array}{l}\text { Welding } \\
\text { fumes }\end{array}$ & 4 & 4 & 16 & Extreme risk \\
\hline & $\begin{array}{l}\text { Fire, explosion, and } \\
\text { health hazards }\end{array}$ & Ignition \& Cutting & 3 & 4 & 12 & Extreme risk \\
\hline & $\begin{array}{l}\text { Fire and explosion } \\
\text { by explosives } \\
\text { flammable } \\
\text { materials }\end{array}$ & Shut-down & 3 & 4 & 12 & Extreme risk \\
\hline & $\begin{array}{l}\text { Fire extinguisher } \\
\text { near cutting, } \\
\text { fireguard, and } \\
\text { health }\end{array}$ & Cutting process & 2 & 4 & 8 & High risk \\
\hline & $\begin{array}{l}\text { Fire, explosion, and } \\
\text { health hazards }\end{array}$ & Cylinder Handling & 2 & 4 & 8 & High risk \\
\hline & Loud noise exposer & $\begin{array}{l}\text { Excess noise associated } \\
\text { with grinding, } \\
\text { hammering, metal } \\
\text { cutting, and other } \\
\text { activities }\end{array}$ & 4 & 2 & 8 & High risk \\
\hline Onboard cutting & $\begin{array}{l}\text { Hazardous } \\
\text { standard of } \\
\text { workplace }\end{array}$ & $\begin{array}{l}\text { Lack of PPE, Negligence } \\
\text { of safety measures while } \\
\text { working }\end{array}$ & 4 & 2 & 8 & High risk \\
\hline \multirow[t]{5}{*}{$\begin{array}{l}\text { Materials mobility, } \\
\text { loading and } \\
\text { Unloading }\end{array}$} & $\begin{array}{l}\text { Struck by materials } \\
\text { while, Unloading } \\
\text { causing injuries, } \\
\text { hand cuts, finger } \\
\text { injuries } \\
\end{array}$ & $\begin{array}{l}\text { Handling heavy objects, } \\
\text { repetitive strain injuries, } \\
\text { excessive workloads }\end{array}$ & 3 & 2 & 6 & High risk \\
\hline & Health injuries & Cutting sheet, Handling & 2 & 2 & 6 & Moderate risk \\
\hline & $\begin{array}{l}\text { Health injuries by } \\
\text { chemical }\end{array}$ & Chemical shifting & 1 & 2 & 2 & Low risk \\
\hline & Health and Fire & Oil Transfer & 3 & 2 & 6 & High risk \\
\hline & $\begin{array}{l}\text { The heavy object } \\
\text { fell on the body }\end{array}$ & $\begin{array}{c}\text { Poor maintenance of } \\
\text { winch, crane/wire, } \\
\text { negligence of safety } \\
\text { measures while working }\end{array}$ & 4 & 4 & 16 & Extreme risk \\
\hline \multirow[t]{2}{*}{$\begin{array}{c}\text { Storage \& } \\
\text { preservation of } \\
\text { hazardous waste }\end{array}$} & Fume inhalation & Oil and chemical, sludge & 4 & 3 & 12 & Extreme risk \\
\hline & $\begin{array}{l}\text { Hazardous } \\
\text { materials and } \\
\text { chemicals, } \\
\text { including heavy } \\
\text { metals in ship } \\
\text { transducers, ballast, } \\
\text { and paint coatings; } \\
\text { mercury in } \\
\text { fluorescent light } \\
\text { tubes, } \\
\text { thermometers, } \\
\text { electrical switches, } \\
\text { light fittings, fire } \\
\text { detectors. }\end{array}$ & $\begin{array}{l}\text { Exposure to hazardous } \\
\text { liquids or gases or } \\
\text { material substances, } \\
\text { combustible materials }\end{array}$ & 4 & 3 & 12 & Extreme risk \\
\hline
\end{tabular}


Table 7. Cont.

\begin{tabular}{|c|c|c|c|c|c|c|}
\hline Operation & $\begin{array}{c}\text { Hazards } \\
\text { Description }\end{array}$ & Causal Risk Factor & Severity & Probability & Risk & Level of Risk \\
\hline & $\begin{array}{l}\text { Health injuries \& } \\
\text { fire }\end{array}$ & Oil and fuel & 4 & 3 & 12 & Extreme risk \\
\hline & Health injuries & $\begin{array}{l}\text { Asbestos in hanger liners, } \\
\text { mastic under isolation, } \\
\text { cloth under isolation, } \\
\text { cable, lagging and } \\
\text { insulation on pipes and } \\
\text { hull, adhesive, gaskets } \\
\text { on piping connections, } \\
\text { and valve packing }\end{array}$ & 4 & 3 & 12 & Extreme risk \\
\hline & Health hazards & $\begin{array}{l}\text { Polychlorinated } \\
\text { biphenyls (PCBs) in } \\
\text { rubber products such as } \\
\text { hoses, plastic foam } \\
\text { isolation, cables, silver } \\
\text { paint, habitability paint, } \\
\text { plates on top of the hull } \\
\text { bottom, and primary } \\
\text { paint on hull steel }\end{array}$ & 4 & 3 & 12 & Extreme risk \\
\hline \multirow[t]{3}{*}{$\begin{array}{c}\text { Storage \& } \\
\text { preservation of } \\
\text { non-hazardous } \\
\text { waste }\end{array}$} & Health hazards & Cutting sheet & 2 & 2 & 4 & Moderate risk \\
\hline & Health hazards & Machinery \& Equipment & 1 & 2 & 2 & Low risk \\
\hline & Health hazards & Spares & 1 & 1 & 1 & Low risk \\
\hline $\begin{array}{l}\text { Clearing of } \\
\text { materials }\end{array}$ & $\begin{array}{l}\text { Manual handling, } \\
\text { dust, cuts from } \\
\text { objects }\end{array}$ & Materials handling & 2 & 1 & 2 & Low risk \\
\hline $\begin{array}{l}\text { Use of mechanical } \\
\text { hammer }\end{array}$ & $\begin{array}{l}\text { Exposure to dust, } \\
\text { noise pollution, } \\
\text { vibrations }\end{array}$ & Cutting & 2 & 3 & 6 & High risk \\
\hline
\end{tabular}

\section{Discussion}

Despite various adverse impacts on the coastal environment, the ship-breaking industry has received considerable attention in Bangladesh's Chattogram region due to the growing demand for raw materials for re-rolling mills, poor and rural livelihoods, and employment opportunities. The ship-breaking worker community is one of the most vulnerable ones in Bangladesh, and year after year, the livelihood conditions of the shipbreaking worker community are getting worse. On the Bhatiari coast, the livelihoods of ship-breaking workers were relatively poor and always remained in a lower economy.

The results revealed that workers in the ship-breaking industry between the ages of 15 and 50 had been seen to engage in ship recycling, representing more than one-third of the workers under 26-30 years and 36-40 years, reflecting an experienced and physically fit workforce. Very little child labor was observed in the wards, demonstrating that the young workforce predominates in this sector, which may be due to a lack of physical strength to work in the ship-breaking yard. Previous research [13] reported that most of the workers, $41.75 \%$, fall under 19-22 years, like the present study. Similar observations were also made by [14]. Most of the workers in the ship-breaking yard were Muslims. Half of the workers were married, indicating that they were responsible for supporting their families. The unmarried were child laborers who were forced to work to support themselves and their families. More than half of the labor forces have their hometowns around the ship-breaking sites, the Chattogram. Simultaneously, the other workers come from poverty-stricken regions of Bangladesh, including Barisal, Khulna, and Comilla. Apart from working in the ship-breaking yards, the workers also reported working as daily laborers, fishers, small 
businesspeople, students, and rickshaw pullers. The survey found that more than $70 \%$ of workers preferred to live in a nuclear family because of their daily expenses and low incomes, and more than forty percent of workers had four to six family members. More or less similar results were found by [16] in the Bhatiari fishing village, where $82 \%$ of fishers were nuclear families, and $18 \%$ were joint.

Education displays a strong relationship between societies. Figure 4 shows that more than $40 \%$ of workers are illiterate, and more than $25 \%$ can only write their names regarding the educational status of workers. Therefore, most workers have less space for better professional jobs inside and outside the industry due to the lack of literacy. The studied areas' education level was like [13], who stated that $45 \%$ of workers were illiterate, followed by $8 \%$ who can only sign, and $41 \%$ with a primary pass.

The survey found that most of the workers work 9-12 $\mathrm{h}$ a day. Workers work an eight-hour shift and are paid an extra four hours of overtime to get the same regular working hours. A similar kind of result was found by $[13,15]$. The investigation found that $35.29-37.66 \%$ of workers have $1-6$ years of experience, $12.99-19.61 \%$ of workers have 7 to 11 years of experience, and $32.47-33.33 \%$ of workers have more than ten years of experience. Previous research [15] stated that $46.29 \%$ of workers had $1-5$ years of experience, $27.77 \%$ of workers had 5-10 years of experience, and $11.11 \%$ had more than ten years.

The housing condition denoted the social and economic status of a community. It can be said that workers working in the ship-breaking yards had been seen living in an unhealthy environment and poor houses. It was observed from the survey that over $65 \%$ of the workers lived in their houses, mainly made of bamboo with straw roofs and mud floors. Therefore, the findings are dissimilar to those from a previous study [16], which stated that $20.20 \%$ of houses were straw roofs and bamboo, $46.46 \%$ were made of tin, and $26.26 \%$ were semi pacca. The differences may be the socio-economic status and the effect of losing a job in the ship-breaking yard.

In a focus-group discussion, workers said their families' financial prudence declined as their homes were affected or damaged after a natural disaster. To withstand that situation, workers have to borrow money from relatives and friends for home repairs and medical needs. Nevertheless, if they cannot get any help, workers tend to borrow money from the moneylender. The investigation found that $30.47 \%$ of workers take a loan from their relatives, followed by $21.88 \%$ from their friends or co-workers, $1.56 \%$ from different banks, and $42.19 \%$ from different NGOs. Other research [17] reported a similar result for the fishermen community in Bhatiari, concluding that $27 \%$ of fishers took a loan from NGOs and $26 \%$ from banks. The availability of drinking water is essential for a community to develop. It was found that $90.20 \%$ to $87.01 \%$ of workers use tube well for drinking water, while $9.80 \%$ to $12.99 \%$ of workers use pond water for drinking (Figure 10). Previous research $[17,18]$ found the same result in the fishermen community of Bhatiari and Baghmara. Moreover, workers have minimal access to health services and inadequate housing, welfare, workers' plight, and sanitation, exacerbating workers' plight. The sanitary facilities and the working condition of the workers were not satisfactory.

In the ship-breaking industry, workers' wages vary according to their job type and experience. They work long hours without safety measures and usually do not have labor contracts. It was found that $47.06 \%$ of people at ward no. 5 have an annual income of USD 832-951, and at ward no. $649.35 \%$ of people have an annual income of USD 832-951. These findings were like $[15,17,19-21]$, who found low-income shipbreaking workers in Bhatiari.

The livelihood index shows changes in the community's livelihood capital, where changes can be positive or negative. Positive change means a development in livelihood, and negative change means vulnerability. Table 3 reveals that Bhatiari ward no. 6 had a more positive change than Bhatiari ward, five in all five capitals. At Bhatiari ward no. 6 , housing conditions were better than ward no. 5 as the change in livelihood capital was more significant in the Bhatiari ward 6. Though Bhatiari no. 6 has a higher percentage of change in livelihood capital, the results showed that development in income, housing condition, and training facilities could help Bhatiari ward no. 5 improve in the future. 
The income level at Bhatiari ward no. 5 was lower than Bhatiari ward no. 6 , and the change in credit facilities was $8.89 \%$ at Bhatiari ward no. 5. In contrast, at ward no. 6 , the percentage was $23.25 \%$. The change was more significant in Bhatiari ward six because they had more credit access to banks and NGOs. At Bhatiari ward no. 6, younger and experienced workers worked in the ship-breaking yard than ward no. 5. Because of that, the change in livelihood capital was positive and higher in ward no. 6. Moreover, no workers had a better relationship with the yard owner and relatives at the ward. Workers at ward no. 5 were more affected by natural disasters than ward no. 6 , and workers at ward no. 6 had more agricultural land, which causes a more significant change in workers' livelihood capital and causes a more remarkable change in workers' livelihood capital.

About 400 deaths and 6000 injuries in yards, mainly due to explosions and falls during cutting, were documented as of 2005, which is still a significant concern [22]. According to the survey, on average, at least one worker was killed or injured in the spot yard every week during the work period. Toxic chemicals, toxic gases (asbestos, polychlorinated biphenylsPCBs, Polyvinyl chloride-PVC), glass fiber, solid foam, and waste oil harm the environment, pollute beach water and air, and damage the lungs, eyes, and muscles of those who work in these yards [23]. Workers reported facing different physical problems while working in the ship-breaking yard. Pollution and the lack of safety procedures combine to make the ship-breaking yards too risky for workers, the environment, neighboring communities, and yard owners if a particularly terrible accident occurs [11]. It is unveiled from the study that maximum cutter group workers had some eye problems as they had to work with the bright light of oxyacetylene. Sometimes they use protective goggles, but these were not adequately made for heavy work like ship-breaking activities. Moreover, they have redness of the eye, tearing, a burning sensation, blurring vision, and blindness.

In the case of respiratory problems, more than one-third of the workers reported suffering from chest pain. In contrast, others reported vomiting, abdominal pain, and abdominal diseases such as anorexia, nausea, vomiting, abdominal pain, and gastric. The main reason for that was smoking, asbestos dust, different toxic gas, and fire. Besides, poor quality food consumption, unsafe drinking water, and inadequate sanitation are responsible for abdominal diseases. Previous research [14] stated that $20.83 \%$ of workers had gastric, and $12.50 \%$ of workers had abdominal pain, which is similar to the result of this study.

The workers suffer from various skin diseases as they must work with toxic metals. Working with toxic metal, fire, and dust is responsible for the skin diseases of ship-breaking workers at Bhatiari. Moreover, the ship-breaking yard workers did not get adequate food for consumption; they had excessive workloads and worked for an hour; thus, they suffered from nutritional deficiency. Previous authors [24,25] reported that the primary health hazards faced by ship-breaking workers were muscle pain $(87 \%)$, visual impairment $(72 \%)$, difficulty breathing (52\%), stomach problems $(81 \%)$, skin diseases $(56 \%)$, and other infections $(28 \%)$, which is very similar to the findings of this study.

The study showed no specific rules and regulations of ship-breaking activities in Bangladesh [16] to safeguard the workers from accidents, the loss of lives, and severe health injuries. It lamented that laws and rules to protect both the workers and the environment are poorly enforced. Owners of ship recycling yards claim that labor and environmental practices have improved over the past few years, and many manual tasks have been automated. Most of the ship-breaking workers claimed to have lost their jobs due to improved machinery and shipyard infrastructure. The employers and shipbreaking owners are excluding them. Besides increasing taxes on metals and iron, most ship owners cannot import ships for scrapping. As a result, most shipbreaking industries have been closed.

Workers are at significant risk due to the lack of infrastructure on the beach and have very little knowledge about the impact of ship breaking on health. Workers working at the Bhatiari ship-breaking yards were uninformed about the safety issue, and a minimal number of workers had protective gear. The negligence of employers poorly monitored 
business operations, the authorities' inability to implement security measures, insufficient training on safe ship-dismantling methods, and the workers who could not get proper protective equipment are the main reasons behind the accidents. Medical facilities for workers were limited and sometimes received a small amount of compensation for injuries. Previous research [20] stated that $88 \%$ of the workers suffered from accidental injury, from a foot injury to more significant accidents. Other authors [16] reported a similar kind of results. One worker said that-

"The main reason for physical hazards was because of a lack of protective gear. The goggles that the owner provided were not of decent quality. Then he said that sometimes they do not get any protective gear; they cut the ship with bare hands and sledgehammer".

At present, the labor authorities must pay immediate attention to these economically significant industrial workers' occupational health and safety standards. They ensure the implementation of a legal and regulatory regime in line with international standards in the ship-breaking industry to protect workers' rights, the environment, and human rights. A ship-dismantling zone integrated with modern facilities should be developed. Apart from that, Bangladesh needs to immediately develop an appropriate authorization and management system to ensure proper management of dangerous goods, environmental protection, and reporting procedures. Clear ship-recycling policy procedures need to be developed to ensure the health and safety of workers. In addition, regular health and hazard audits of the sites are essential to ensure the sustainability of the regulations.

No government body mainly deals with shipbreaking activities; instead, the issue is dealt with by the concerned ministry in Bangladesh. There is no enforcement of the Labor Laws, no legally binding framework in international commitments, no environmental standard set for the industry, and no institutional arrangement for monitoring ship-breaking activities. There is no consolidated policy or strategy or guideline in Bangladesh for ship dismantling, and there is also a severe lack of communication between the responsible Ministries. Therefore, there is a need for a sustainable and eco-friendly policy for ship-breaking activities in Bangladesh. Moreover, many governmental organizations and NGOs were found to support ship-dismantling workers, including legal aid and support or claims for compensation, primary health care, training, and informal information sessions. To assess the various impacts of the ship-building industry on the local environment and worker health, short-term and long-term scientific research in coastal areas should be initiated immediately. Several initiatives including institutional, technical, regulatory, awareness-raising, adoption of standards, enforcement of laws, inspections, capacity building, guideline development for occupational health and safety, guideline development for cleaner production measures in the ship-breaking industry (to phase out pollutants), and the implementation of minimum standards for environmental protection and an occupational health and safety plan shall be taken to improve the situation. Institutional capacity in state regulators, regular inspection and monitoring, yard owner attitudes, initial investment, and general policies can be critical factors in ensuring the industry's sustainability.

\section{Conclusions}

Ship-breaking workers are among the most vulnerable communities in Bangladesh due to frequent accidents and occupational health hazards. Despite various health hazards, many workers from Bhatiari rely on the ship-breaking industry to maintain their livelihood. In contrast, more than a third of the workers had 1 to 6 years of work experience. Due to the lack of pure drinking water, healthy food, and sanitary toilets, ship-breaking workers' livelihood was unsatisfactory. The present study also revealed that the entire shipdismantling process remains labor-intensive and risky. Worker safety is jeopardized due to a lack of safety measures and proper planning. Therefore, the study recommends providing compensation, treatment, and safety for workers, establishing fire stations and hospitals close to shipyards for workers' welfare, and avoiding severe losses from any accident. 
Author Contributions: A.F.A.: Writing, original draft preparation, P.S.: Data curation, Funding acquisition, and editing, R.K.: Data analyzing, supervision, M.M.H.M.: Reviewing, editing, S.J.M.: Visualization and M.M.S.: Conceptualization, methodology, supervision, writing and reviewing. All authors have read and agreed to the published version of the manuscript.

Funding: This research received no external funding.

Institutional Review Board Statement: Not applicable.

Informed Consent Statement: Informed consent was obtained from all subjects involved in the study.

Data Availability Statement: Not applicable.

Conflicts of Interest: The authors declare no conflict of interest.

\section{References}

1. Demaria, F. Can the poor resist capital? Conflicts over 'Accumulation by Contamination 'at the ship-breaking yard of Alang (India). In Nature, Economy, and Society; Springer: New Delhi, India, 2016; pp. 273-304.

2. Fakhruddin, A.N.M.; Talukdar, M.I.; Hossain, M.A. Environmental Impacts of Ship Breaking and Recycling Industry of Sitakunda, Chittagong, Bangladesh. Adv. Nat. Sci. 2015, 8, 51-58.

3. Hossain, M.S.; Fakhruddin, A.N.M.; Chowdhury, M.A.Z.; Gan, S.H. Impact of ship-breaking activities on the coastal environment of Bangladesh and a management system for its sustainability. Environ. Sci. Policy 2016, 60, 84-94. [CrossRef]

4. BSBA 2011: Safety Measures Taken for Workers. Bangladesh Ship Breakers Association. Available online: http://www.bsba.org. $\mathrm{bd} /$ page.php?id=13 (accessed on 10 June 2021).

5. Iqbal, K.S.; Zakaria, N.G.; Hossain, K.A. Identifying and Analysing Underlying Problems of Shipbuilding Industries in Bangladesh. J. Mech. Eng. 2010, 41, 147-158. [CrossRef]

6. Rabbi, H.R.; Rahman, A. Ship breaking and recycling industry of Bangladesh; issues and challenges. Procedia Eng. 2017, 194, 254-259. [CrossRef]

7. Gunbeyaz, S.A.; Kurt, R.E.; Baumler, R. A study on evaluating the status of current occupational training in the ship recycling industry in Bangladesh. WMU J. Marit. Aff. 2019, 18, 41-59. [CrossRef]

8. Rahman, S.M.; Mayer, A.L. Policy compliance recommendations for international shipbreaking treaties for Bangladesh. Mar. Policy 2016, 73, 122-129. [CrossRef]

9. Alam, S.; Faruque, A. Legal regulation of the shipbreaking industry in Bangladesh: The international regulatory framework and domestic implementation challenges. Mar. Policy 2014, 47, 46-56. [CrossRef]

10. Roy, B. Health Problems among the Workers in the Ship-Breaking Industry; Department of Occupatioal and Environmental Health, Natioanl Institute of Preventive and Social Medicine (NIPSOM): Dhaka, Bangladesh, 2003.

11. Chowdhury, S. Bangladesh's ship breaking Industry: A Stakeholder Analysis. In Governance and Sustainability; Emerald Publishing Limited: Bingley, UK, 2020; pp. 173-184. [CrossRef]

12. Lindenberg, M. Measuring household livelihood security at the family and community level in the developing world. World Dev. 2002, 30, 301-318. [CrossRef]

13. Kutub, M.J.R.; Falgunee, N.; Nawfee, S.M.; Rabby, Y.W. Ship breaking industries and their impacts on the local people and environment of coastal areas of Bangladesh. Hum. Soc. Stud. 2017, 6, 35-58. [CrossRef]

14. Chowdhury, P.A.; Ali, M.M.; Shahjahan, A.T.M. Impacts of Ship Breaking Industries on Environment and Socio-Economic Condition of Bangladesh-A Case Study of Sitakunda Shitolpur Ship Breaking Yard, Chittagong. Master's Thesis, Chittagong University of Engineering \& Technology, Chittagong, Bangladesh, 2015.

15. Hossain, M.S.; Chowdhury, S.R.; Jabbar, S.A.; Saifullah, S.M.; Rahman, M.A. Occupational health hazards of ship scrapping workers at Chittagong coastal zone, Bangladesh. Chiang Mai J. Sci. 2008, 35, 370-381.

16. Muhibbullah, M. Health Hazards and Risks Vulnerability of Shipbreaking Workers: A Case Study on Sitakunda Shipbreaking Industrial Area of Bangladesh Global Advanced Research. J. Geogr. Reg. Plan. 2013, 2, 172-184.

17. Sarraf, M.; Stuer-Lauridsen, F.; Dyoulgerov, M.; Bloch, R.; Wingfield, S.; Watkinson, R. The Ship Breaking and Recycling Industry in Bangladesh and Pakistan. 2010. Available online: http://crossasia-repository.ub.uni-heidelberg.de/3749/1/Ship\%20 Breaking\%20and\%20Recycling\%20Industry.pdf (accessed on 11 June 2021).

18. Billah, M.M.; Kader, M.A.; Siddiqui, A.A.M.; Shoeb, S. Studies on fisheries status and socio-economic condition of fishing community in Bhatiary coastal area Chittagong, Bangladesh. J. Entomol. Zool. Stud. 2018, 6, 673-679.

19. Ali, M.H.; Hossain, M.D.; Hasan, A.N.G.M.; Bashar, M.A. Assessment of the livelihood status of the fish farmers in some selected areas of Bagmara upazilla under Rajshahi district. J. Bangladesh Agric. Univ. 2008, 6, 367-374. [CrossRef]

20. Hossain, M.M.M.; Islam, M.M. Ship Breaking Activities and Its Impact on the Coastal Zone of Chittagong, Bangladesh: Towards Sustainable Management; Advocacy \& Publication Unit, Young Power in Social Action (YPSA): Chittagong, Bangladesh, 2006.

21. Alam, G.M. An Assessment of the Livelihood Vulnerability of the Riverbank Erosion Hazard and Its Impact on Food Security for Rural Households in Bangladesh. Ph.D. Thesis, University of Southern Queensland, Darling Heights, QLD, Australia, 2016. 
22. Sujauddin, M.; Koide, R.; Komatsu, T.; Hossain, M.M.; Tokoro, C.; Murakami, S. Characterization of ship breaking industry in Bangladesh. J. Mater. Cycles Waste Manag. 2015, 17, 72-83. [CrossRef]

23. YPSA. Ship Breaking in Bangladesh. Youth Power in Social Action.. 2014. Available online: http://www.Shipbreakingbd.info/ (accessed on 13 June 2021).

24. Rousmaniere, P.; Raj, N. Shipbreaking in the developing world: Problems and prospects. Int. J. Occup. Environ. Health 2007, 13, 359-368. [CrossRef] [PubMed]

25. Zhang, W.; Stern, D.; Liu, X.; Cai, W.; Wang, C. An analysis of the costs of energy saving and CO2 mitigation in rural households in China. J. Clean. Prod. 2017, 165, 734-745. [CrossRef] 